\title{
Diversity of Insect Flower Visitors of Xylopia aromatica (Magnoliales, Annonaceae) in a Brazilian Savanna
}

\author{
Fábio Pinheiro Saravy ${ }^{1}\left(\mathbb{D}\right.$, Karl-L. Schuchmann ${ }^{1,2,3, *(\mathbb{D})}$ and Marinez I. Marques ${ }^{1,2}(\mathbb{D}$ \\ 1 Postgraduate Program in Zoology, Institute of Biosciences, Federal University of Mato Grosso (UFMT), \\ Fernando Correa da Costa Av. 2367, Cuiabá 78060-900, MT, Brazil; biofazoologia@gmail.com (F.P.S.); \\ marinez513@gmail.com (M.I.M.) \\ 2 Computational Bioacoustics Research Unit (CO.BRA), National Institute for Science and Technology in \\ Wetlands (INAU), Federal University of Mato Grosso (UFMT), Fernando Correa da Costa Av. 2367, \\ Cuiabá 78060-900, MT, Brazil \\ 3 Zoological Research Museum A. Koenig (ZFMK), Ornithology, Adenauerallee 160, 53113 Bonn, Germany \\ * Correspondence: klschuchmann@googlemail.com
}

Citation: Pinheiro Saravy, F.

Schuchmann, K.-L.; Marques, M.I.

Diversity of Insect Flower Visitors of Xylopia aromatica (Magnoliales, Annonaceae) in a Brazilian Savanna. Diversity 2021, 13, 661. https:// doi.org/10.3390/d13120661

Academic Editors: Michael Wink and Viktor Brygadyrenko

Received: 18 November 2021

Accepted: 8 December 2021

Published: 11 December 2021

Publisher's Note: MDPI stays neutral with regard to jurisdictional claims in published maps and institutional affiliations.

Copyright: (c) 2021 by the authors. Licensee MDPI, Basel, Switzerland. This article is an open access article distributed under the terms and conditions of the Creative Commons Attribution (CC BY) license (https:// creativecommons.org/licenses/by/ $4.0 /)$.
Abstract: Small beetles are important pollinators of Annonaceae whose flower chambers are small and have diurnal and/or nocturnal anthesis. The pollinators of these flowers belong to the families Nitidulidae, Staphylinidae, Chrysomelidae, and Curculionidae. In this study, the first conducted in the Cerrado of Chapada dos Guimarães, Mato Grosso, Brazil, the behavior of the insect flower visitors of Xylopia aromatica was observed, in both the field and the laboratory. The chambers of 253 flowers were collected from 11 plants, and the biological aspects of their visitors were analyzed quantitatively and qualitatively. The most abundant visitors were thrips and beetles. Coleoptera was represented by four morphospecies occurring frequently in the floral chambers ( $>70 \%$ of individuals). Among beetles, one species belonged to Nitidulidae (Cillaeinae, Conotelus sp. 1) and two belonged to Staphylinidae (Aleocharinae sp. 1 and Aleocharinae sp. 2). These three morphospecies of small elongate beetles have setae where pollen may adhere. In addition, they were present on both male and female phases of the flowers, indicating potential cross-pollination. In the study area, X. aromatica possesses mixed pollination promoted by Thysanoptera and small Nitidulidae and Staphylinidae beetles. This study brings the first record of Lamprosomatinae (Chrysomelidae) and, especially, of Conotelus (Nitidulidae) in the flower chambers of X. aromatica, with new information on behavior of floral visitors coupled with their morphological traits that may promote cross-pollination in this plant species.

Keywords: Annonaceae; Coleoptera; Cerrado; Cillaeinae; Nitidulidae; pollinator behavior; Staphylinidae; Thysanoptera

\section{Introduction}

Biotic interactions and their diversity are deemed keepers of biodiversity in many communities [1]. The causes of insect diversification in the Mesozoic are still under debate. Some authors explain the diversification of insect lineages as an effect of angiosperm radiation [2]. However, in recent decades, the opposite has been conjectured by Crowson [3] and Jolivet [4]. These authors suggested that the closing of carpels and the appearance of angiosperms may have occurred as an adaptation to beetle predation.

Currently, modern associations between angiosperms and Coleoptera are very diverse and of great ecological and economic importance worldwide. Beetles may be serious pests of fruit cultivars, such as the Nitidulidae subfamily Carpophilinae [5-7] and several Curculionidae subfamilies [8-10]. In Brazil, beetles of the genera Cyclocephala and Phyllophaga (Scarabaeoidea, Melolonthidae) are pests of cereal crops, such as sunflower and soybean $[11,12]$. 
On the other hand, coleopteran taxa are also important pollinators of plants from many families: nitidulids pollinate Arecaceae (palms) and Annonaceae [13-17]; weevils stand out as pollinators of Arecaceae, Annonaceae, and Cyclanthaceae [13,18-21]; and many scarabs of the genus Cyclocephala have been reported as primary pollinators of plants of the families Annonaceae and Araceae [22-24].

The Pantropical Annonaceae stand out as one of the major groups of cantharophilous angiosperms, with nearly $90 \%$ of c. 2430 described species being beetle-pollinated [25-27]. The diverse reproductive biology of these plants is mirrored by the diversity of Coleoptera that promote their pollination, e.g., many genera of Nitidulidae $[15,25,28]$, some members of Curculionidae [20,25], and many species from the scarab tribe Cyclocephalini [25,29,30].

Approximately 280 Annonaceae species occur in the Brazilian Amazon, which makes it the seventh most biodiverse angiosperm family in this phytogeographical domain [31]. In Cerrado areas, a Neotropical savanna biome, there are records for 75 species of Annonaceae [32]. The genus Xylopia is the only genus with a Pantropical distribution in the family and possesses approximately 160 described species [33]. Xylopia aromatica (Lam.) Mart. is one of the most common plant species in several savanna vegetation physiognomies of Cerrado sensu lato: Mata Ciliar, Mata Seca, Cerradão, Cerrado sensu stricto, Vereda, and Amazonian savannas [32]. Despite this species being a typical element in the Cerrados, its geographic distribution, which includes all of the Brazilian states in which Cerrado sensu lato occurs, stretches northward through the Amazon and Central America up to Cuba (Figure 1).

The pollination biology of X. aromatica has been described for Cerrado areas in the states of Bahia [34], São Paulo, Amazonas, and Minas Gerais [35]. For these different areas, insect taxa described as pollinators vary greatly: while Aragão et al. [34] observed weevils as main visitors and pollinators of X. aromatica, Gottsberger and SilberbauerGottsberger [35] mentioned insects of the order Thysanoptera as principal pollinators and beetles as secondary pollinators. According to the latter research, depending on the geographical localization in which $X$. aromatica was studied, beetle taxa found inside flowers differed even at the family level.

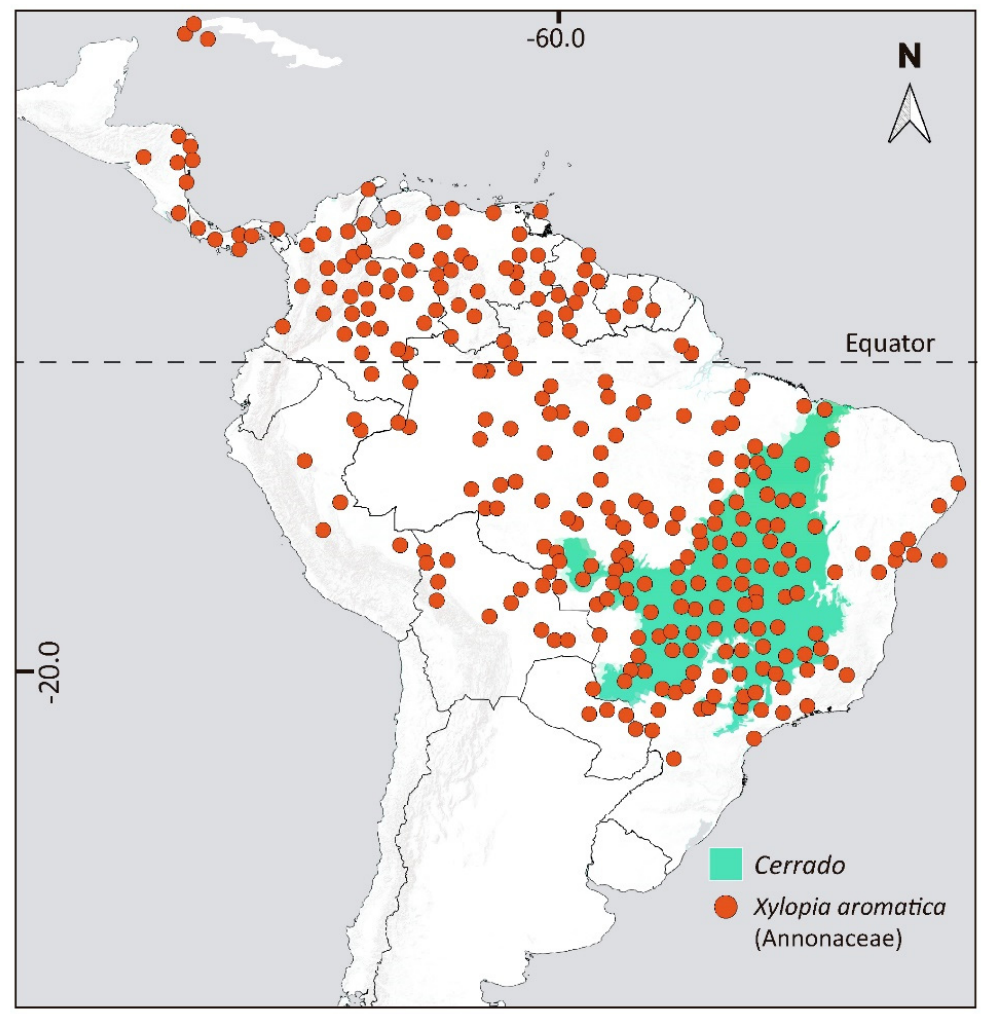

Figure 1. Neotropical distribution of Xylopia aromatica (pimenta-de-macaco). Adapted from: Global Biodiversity Information Facility (GBIF, 2021) [36]. 
Based on the hypothesis that geographic variations influence the assemblage of floral visitors, this study aims to (1) determine which beetle taxa are floral visitors of Xylopia aromatica in the Cerrado study area, (2) confirm whether the behavior of these taxa indicates them as pollinators of this Annonaceae species, and (3) describe natural history traits of the interaction between this angiosperm species and its coleopteran visitors.

\section{Materials and Methods}

\subsection{Study Area}

The study was conducted at the beginning of the rainy season of 2019, during 16 days between September and December, totaling c. $192 \mathrm{~h}$ of field work, in a Cerrado area of Chapada dos Guimarães, Mato Grosso, Brazil, of approximately 20 ha $\left(15^{\circ} 47^{\prime} \mathrm{S}, 55^{\circ} 47^{\prime} \mathrm{W}\right)$. Following the identification key of savanna vegetation physiognomies in the Cerrado by Ribeiro and Walter [37], the area in which the sampled individuals of X. aromatica were located was characterized as Cerrado Denso, bordered to the northwest by a patch of Mata de Galeria Não-Inundável and to the southeast by a stretch of Mata Seca (Figure 2). The regional climate, according to the Köppen classification, is type Aw. The mean annual temperature is $21.5^{\circ} \mathrm{C}$, and the average annual rainfall may reach $2100 \mathrm{~mm}$ in higher elevation areas [38]. Sampled individuals of X. aromatica $(n=11)$ were scattered at elevations from 737 to $817 \mathrm{~m}$.

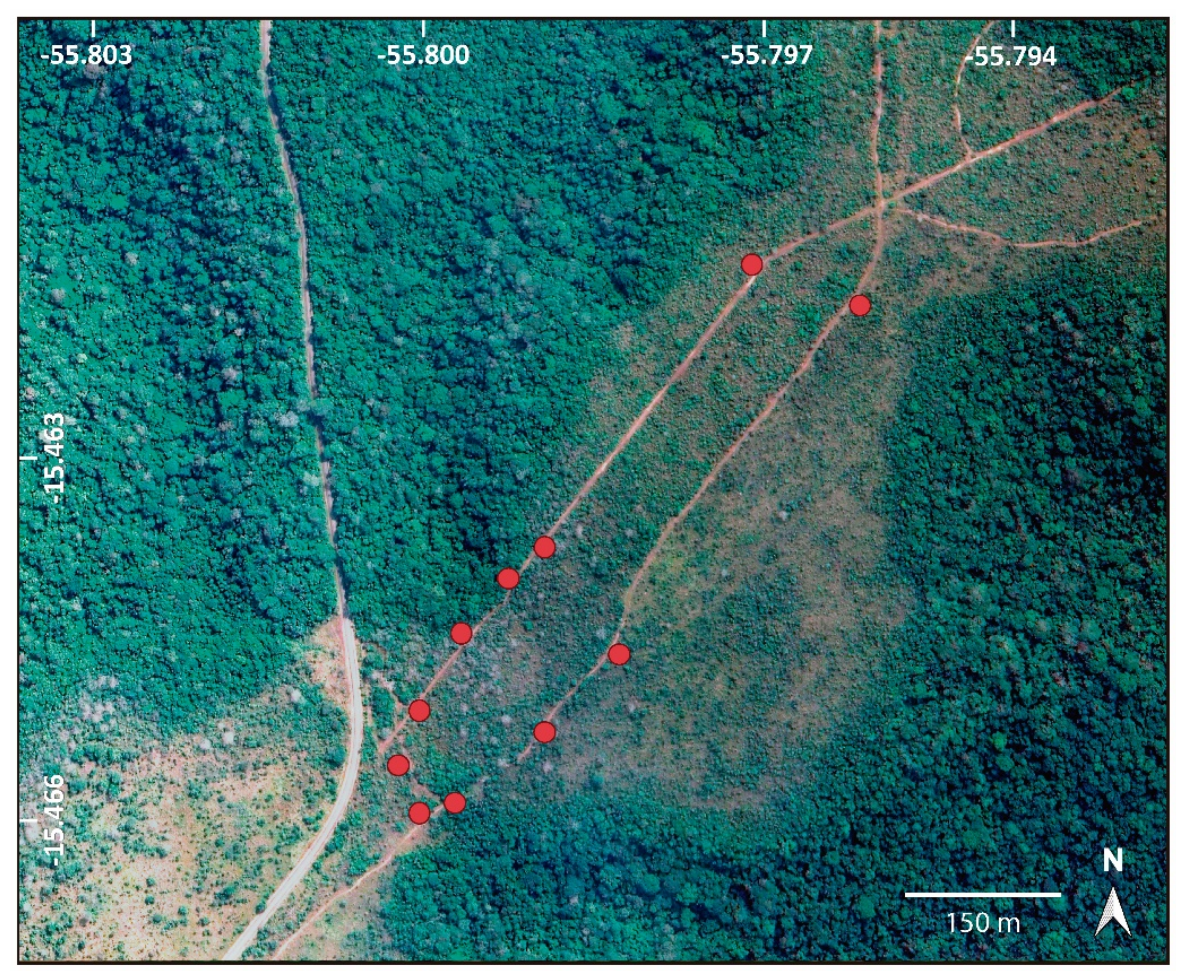

Figure 2. Satellite image of the study area located in the Cerrado of Chapada dos Guimarães, MT, Brazil, indicating the 11 sampled individuals of Xylopia aromatica (red circles). Source: Google Earth.

\subsection{Sampling of Floral Visitors}

The 11 individuals of Xylopia aromatica were selected on the basis of access to flowers, ruling out individuals whose flowers were too high on the crowns. Another criterion deployed for the selection of these individuals was the abundance of flowers. Floral observations and collections were performed following a diuturnal regime at all times of day, except from $0300 \mathrm{~h}$ to $0700 \mathrm{~h}$. Inner and outer petals of $X$. aromatica flowers form a floral chamber where, during most parts of anthesis, floral visitors remain trapped. The most accessible anthetic flowers were randomly picked from X. aromatica individuals and stored in $90 \%$ alcohol. The geographic coordinates, together with the time and day of each flower collection, were recorded. Each flower was put into an individual plastic vial 
labeled with field data. Flowers were analyzed at the Laboratório de Ecologia e Taxonomia de Artrópodes (LETA) at the Instituto de Biociências at the Universidade Federal de Mato Grosso. In total, the contents of 253 floral chambers were analyzed.

Behavioral and morphological traits of visiting insects were considered appropriate for pollinating action when (1) floral visitors were found inside the floral chambers; (2) species were found inside the floral chambers in the female and male phases; and/or (3) pollen was adhered to the floral visitors' bodies; and/or (4) floral visitors had conspicuous setae where pollen might adhere.

Field photographic records were obtained with a Sony NEX-F3 digital camera. Photographs of the laboratory material examined were obtained with a Leica CH-94335 microscope camera coupled with a Leica L2 stereomicroscope (Leica Microsystems) and Leica Application Suite v. 3.8 software. The images highlighting certain aspects of floral visitors and/or flowers were obtained by means of multifocal sequences stacked and grouped with Adobe Photoshop 2020 v. 21.0.2 software.

All non-coleopteran floral visitors of Hexapoda were identified at the taxonomic level of order (with the exception of Formicidae). Floral visitors of Coleoptera were identified at the most inferior taxonomic category possible. Photographs were sent to specialists of the subfamilies Carpophilinae, Nitidulinae, and Cillaeinae (Nitidulidae) for identification confirmation. Mites were identified as Acariformes (the superorder Acariformes sensu Brusca et al.) [39]. Spiders were listed as Araneae (the order Araneae sensu Brusca et al.) [39]. Classification of beetles in superior taxonomic categories follows Bouchard et al. [40].

\section{Results}

From September to December 2019, the individuals of X. aromatica $(n=11)$ flowered abundantly in the study area. This species' flowers possess three slender-elliptical outer petals whose abaxial face is red and adaxial face is white. In the immediately upper whorl, alternating with the external petals, three white and linear inner petals of approximately the same length delimit the flower chamber. The base of the inner petals, at the level of the floral chamber, has a reddish area on both the adaxial and abaxial surfaces.

The erect floral bud exposes only the red abaxial surface of the outer petals (Figure 3a). During the early morning hours $(0600 \mathrm{~h}-0900 \mathrm{~h})$, anthesis commences when the outer petals abruptly part from base to apex (Figure $3 b$ ), displaying the inner face of the outer petals and the inner petals (Figure 3c,d). The inner petals are fused at the base, where they acquire a reddish tinge (Figure $3 \mathrm{~d}$ ), and, at the onset of anthesis, delimit only a small aperture of the floral chamber through which it is possible to view the white and salient gynoecium, i.e., the group of female reproductive organs (Figure 4a). At this time, the gynoecium is covered with a sticky, viscous, and shiny substance, the stigmatic exudate. The flowers give off a slightly sweet aroma that intensifies throughout the day.

In the early afternoon hours ( $1200 \mathrm{~h}-1400 \mathrm{~h}$ ), the inner petals close at the base, trapping floral visitors within them (Figure $4 \mathrm{~b}$ ). The flowers remain this way until the end of anthesis, making it impossible to observe, except for a slight darkening of the white adaxial surface of the outer petals, the transition from the female to male phase (Figure 4c). On the second day of anthesis, a spermatic scent is perceptible that denotes the beginning of the shorter male phase. However, the transition to the male phase is only unequivocally noticeable when manually detaching the corolla, opening the floral chamber, and observing the open anthers and pollen scattered on the inside.

In the laboratory, floral chambers were manually opened, and it was possible to see that flowers $(n=234)$ collected at all times of day (except from $0300 \mathrm{~h}$ to $0700 \mathrm{~h}$ ) were in the female phase. For the flowers collected in the morning ( 08:00) of the second day of anthesis, up to $1600 \mathrm{~h}$, the stigmatic head was detached from the receptacle $(n=19)$. During this interval, the anthers were open, and pollen tetrads were scattered inside the floral chamber. In the field, it was possible to observe the dropping of petals during different times in the afternoon of the second day of anthesis, marking the end of the floral cycle. Therefore, anthesis lasts for 25 to $33 \mathrm{~h}$ (Table 1). From this time, the floral chambers remain 
open and, consequently, accessible to their visitors for only approximately the four initial hours of anthesis (0800 h-1200 h). The inner and outer petals are fleshy and serve as food for many phytophagous insects (Figure $4 \mathrm{~d}$ ).

Of the 253 sampled flowers, only 18 (7.11\%) did not possess floral visitors (Figure 5a). The number of flowers in which Coleoptera were present totaled $110(43.87 \%)$ out of 253 (Figure 5b). Thysanoptera was the insect order present in the most flowers, 213 (84.18\%) out of 253 flowers (Figure 5c). The numbers of flowers in which other arthropod orders were present are shown in Figure $5 c$. The remaining groups of arthropods were less abundant (Figure 5d). Moreover, they were present in other parts of flowers because, in the laboratory, they were observed in the alcohol of the samples rather than inside floral chambers, which demonstrates the insignificant role they play in pollination.

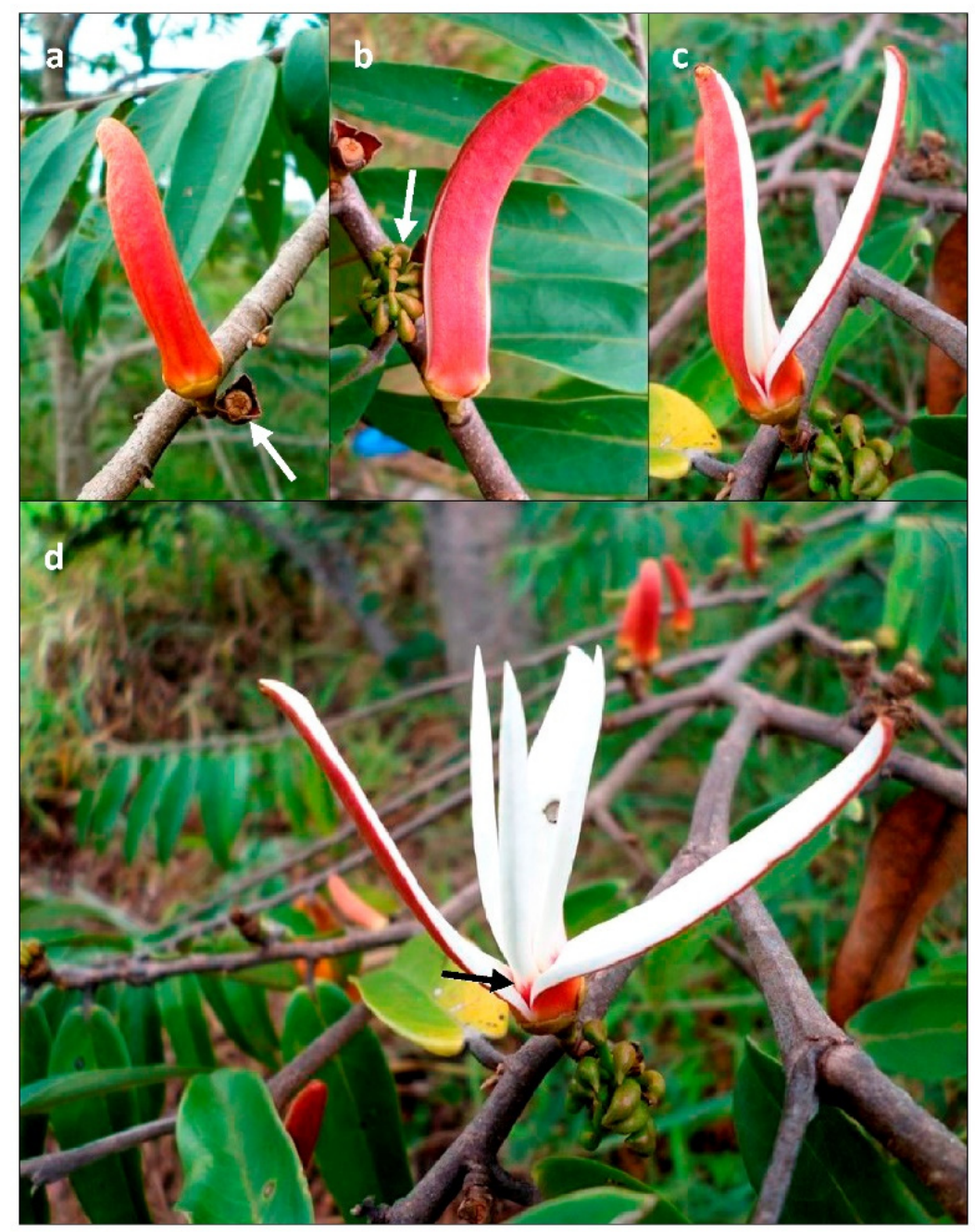

Figure 3. Beginning of anthesis of Xylopia aromatica during the early morning hours (0600 h-0900 h) in the Cerrado of Chapada dos Guimarães, MT. (a) Closed floral bud, exposing only the reddish adaxial surface of the outer petals. Note that, on the side, petals have already dropped, leaving only the calyx attached to the receptacle (arrow). (b) External petals initiate parting from base to apex. Note the apocarpous fruit, to the left, already in development (arrow). (c) An outer petal bends outwards, exposing two inner petals. (d) Opened flowers, with inner petals still enclosing the floral chamber. Note the reddish patch at the base of an inner petal (arrow). 


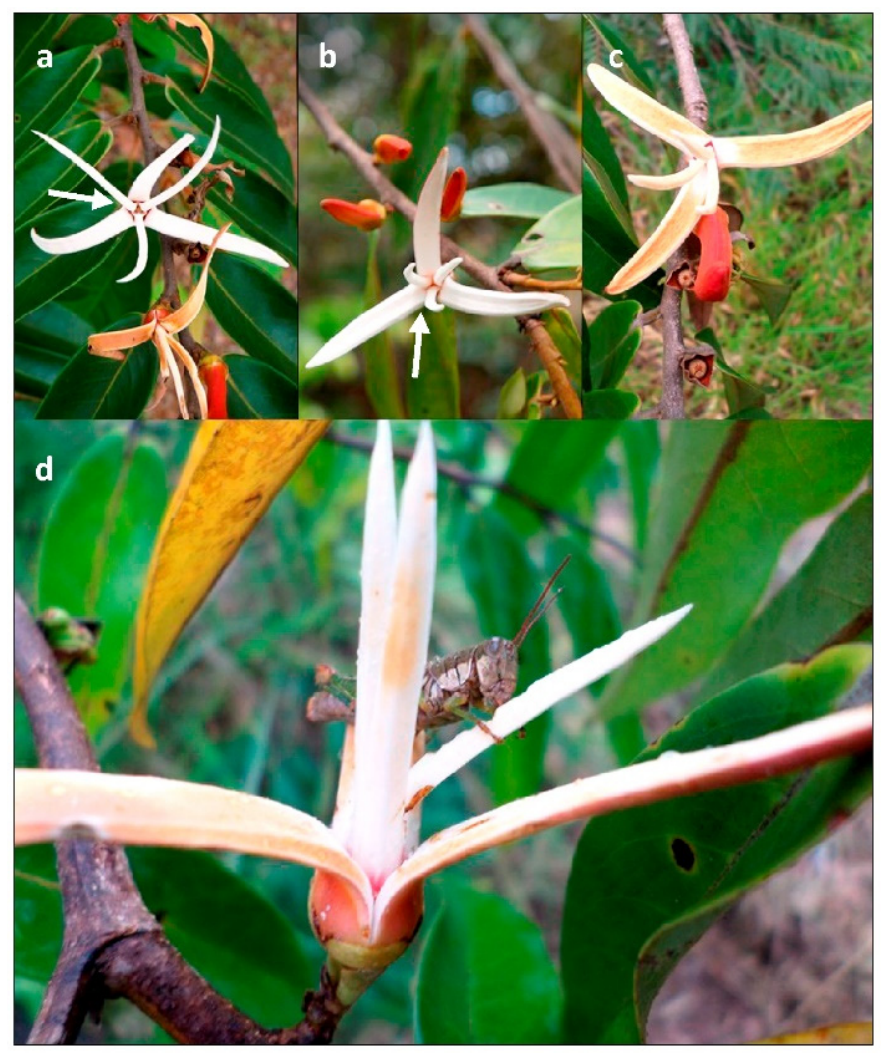

Figure 4. Stages in the anthesis of Xylopia aromatica in the Cerrado of Chapada dos Guimarães, MT, Brazil. (a) Immediately after the opening of the corolla, in the early morning, the inner petals part at the base, leaving the floral chamber open and the gynoecium exposed (arrow). This step lasts, at most, only up to midday. Note, immediately below, a flower at the final stage of anthesis, with its darkened corolla. (b) Until midday, at most, the inner petals close (arrow), trapping the small floral visitors inside the chamber. (c) Flower on the second day of anthesis, already in the male-phase, with the darkened adaxial surface. (d) The fleshy petals of X. aromatica serve as food for several phytophagous insects, such as this immature unidentified Orthoptera.

Table 1. Data on the floral phase of sampled flowers in the Cerrado of Chapada dos Guimarães, MT, Brazil. The column "Time of collections" refers to the hours in which each floral phase was sampled in the field.

\begin{tabular}{ccccc}
\hline Floral Phase & No. of Flowers & \% of Flowers & Time of Collection & \\
\hline Female & 234 & 94.46 & All hours & (1st day) \\
Male & 19 & 5.54 & $07: 05$ to $16: 05$ & (2nd day) \\
\hline
\end{tabular}

The most abundant insect order (insects / flower) was also Thysanoptera (mean $=7.42$; $\min .=1$, max. $=57)$. Coleoptera was the second most abundant order per flower $($ mean $=1.63$; $\min .=1$, $\max .=14)$. Figure 6 shows the abundance distributions of Thysanoptera and Coleoptera per sampled flower. The abundance of both Thysanoptera and Coleoptera follows a Poisson distribution, with few cases of more than one individual/flower for each order (Figure $6 b, c)$. The Coleoptera individuals found visiting flowers of $X$. aromatica belonged to four families: Nitidulidae $(n=162)$, Staphylinidae $(n=39)$, Chrysomelidae $(n=8)$, and Curculionidae $(n=1)$ (Figure 7a). The number of flowers in which each family was present is shown in Figure $7 \mathrm{~b}$. The most abundant families sometimes co-occurred in the same flowers, whether inside or outside of floral chambers, which was the case for the two most common sampled families: Nitidulidae and Staphylinidae (data not shown). 


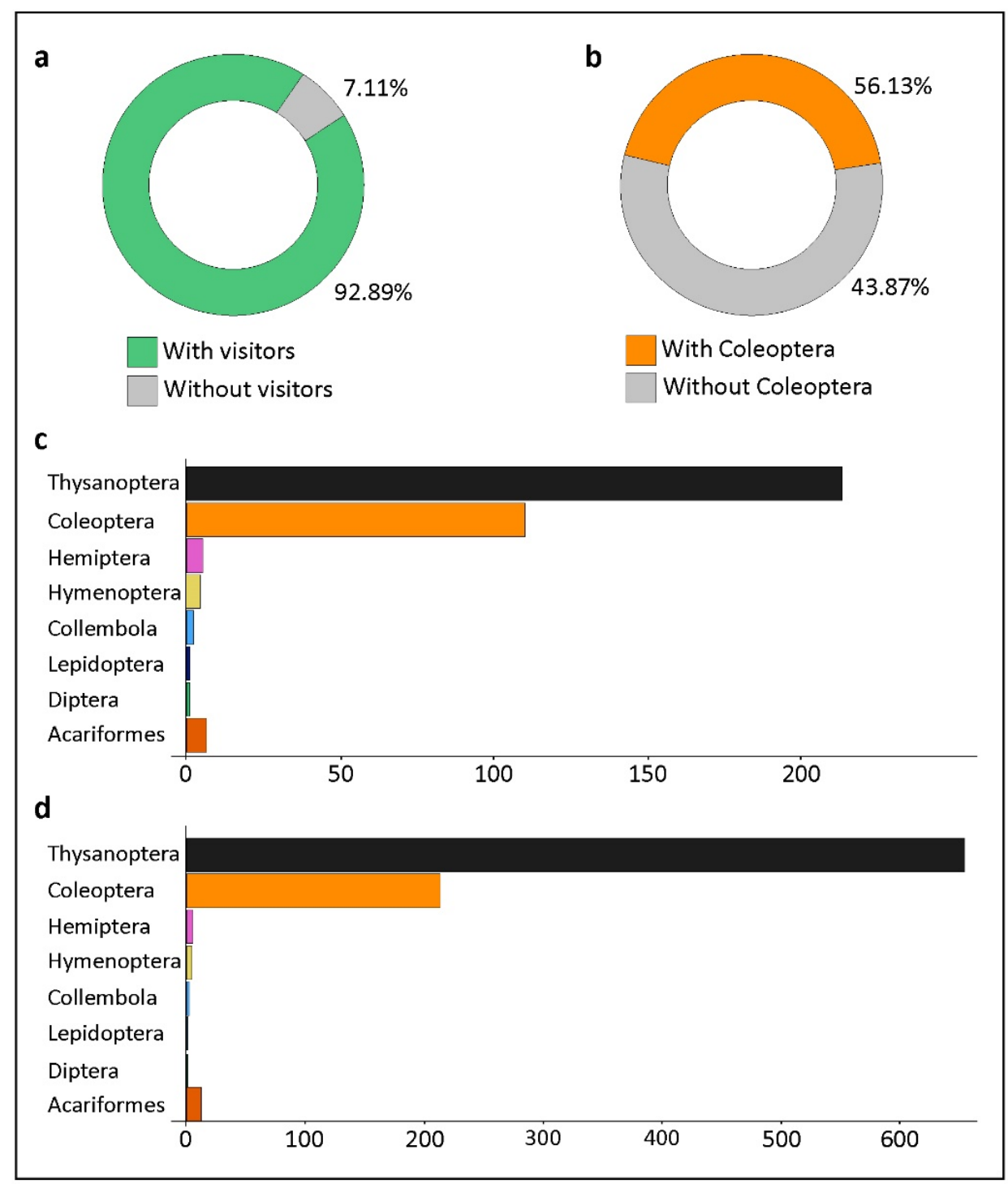

Figure 5. Quantitative data on floral visitors of Xylopia aromatica collected in the Cerrado of Chapada dos Guimarães, MT, Brazil. (a) Percentages of flowers with and without floral visitors. (b) Percentages of flowers with and without coleopteran visitors. (c) Number of flowers in which the indicated groups of arthropod floral visitors were present. (d) Abundance of floral visitors sorted by superior taxonomic categories from the 253 sampled flowers.

The adult Coleoptera taxa found in the $X$. aromatica flowers and some quantitative data are shown in Table 2. Nitidulidae, represented by the subfamilies Cillaeinae, Nitidulinae, Meligethinae, and Carpophilinae, was the coleopteran family that most frequently visited $X$. aromatica flowers, followed by Staphylinidae, with two morphospecies: Aleocharinae sp. 1 and Aleocharinae sp. 2 (Figure 8). The occurrence of Meligethinae (Figure 9a,b), Carpophilinae (Figure 9c,d), Chrysomelidae and Curculionidae was not extensive, and their behavior did not render them effective pollinators of $X$. aromatica since they were not frequently found within floral chambers. However, of the eight sampled individuals of Chrysomelidae, three were found inside floral chambers: two individuals of Lamprosomatinae sp. 1 and one of Chrysomelidae sp. 1 (Figure 10; Table 2), which requires further taxonomic identifications. The pollinating behavior of beetles that visited the flowers of $X$. aromatica was more expressive in the two most abundant families: Nitidulidae and Staphylinidae (Figures 11-14).

The most distinctively frequent Nitidulidae in X. aromatica flowers belonged to the subfamily Cillaeinae (99.14\%; Figure 8a; Table 2). In contrast to the most common morpho- 
logical pattern in nitidulids, which have an oval to rounded shape [41], the Cillaeinae are elongated (Figures 11 and 12). Of the four Nitidulidae morphospecies listed in Table 2, for instance, only Conotelus sp. 1 shows this shape.

Conotelus sp. 1 was frequently observed inside floral chambers: on the androecium (Figure 12a), adhered to the stigmatic exudate of the gynoecium (Figure 12b) and in the concavity situated at the base of the inner petals (Figure 12c). Pollen, when found coating body parts of Conotelus sp. 1, was clustered especially over the abdominal surface and adhered to the conspicuous ventral and ventrolateral setae of sternites (Figure 11c,d).

Both morphospecies of Aleocharinae, Aleocharinae sp. 1 and sp. 2, were observed inside floral chambers, especially Aleocharinae sp. 1 (Table 2; Figures 13 and 14). The sampled staphylinids were smaller and less frequent in flowers than the main coleopteran visitor, Conotelus sp. 1. Nevertheless, their behavior appears to be similar to that of Cillaeinae because beetles from both groups were observed on the androecium and gynoecium (Figure 13c). Body contact of beetles with these reproductive structures favors the transfer of pollen tetrads to stigmas. No conspecific pollen load, however, was detected in the indumentum of sampled staphylinids. The Thysanoptera, which most frequently visited flowers of $X$. aromatica (Figure $5 c, d$ ), also demonstrated behavior tending to result in pollination. They were observed sucking the concave inner face of the inner petals (Figure 15a), feeding on stigmatic exudate (Figure 15b) and over the androecium (Figure 15c). No conspecific pollen load, however, was detected on the setae of these insects.

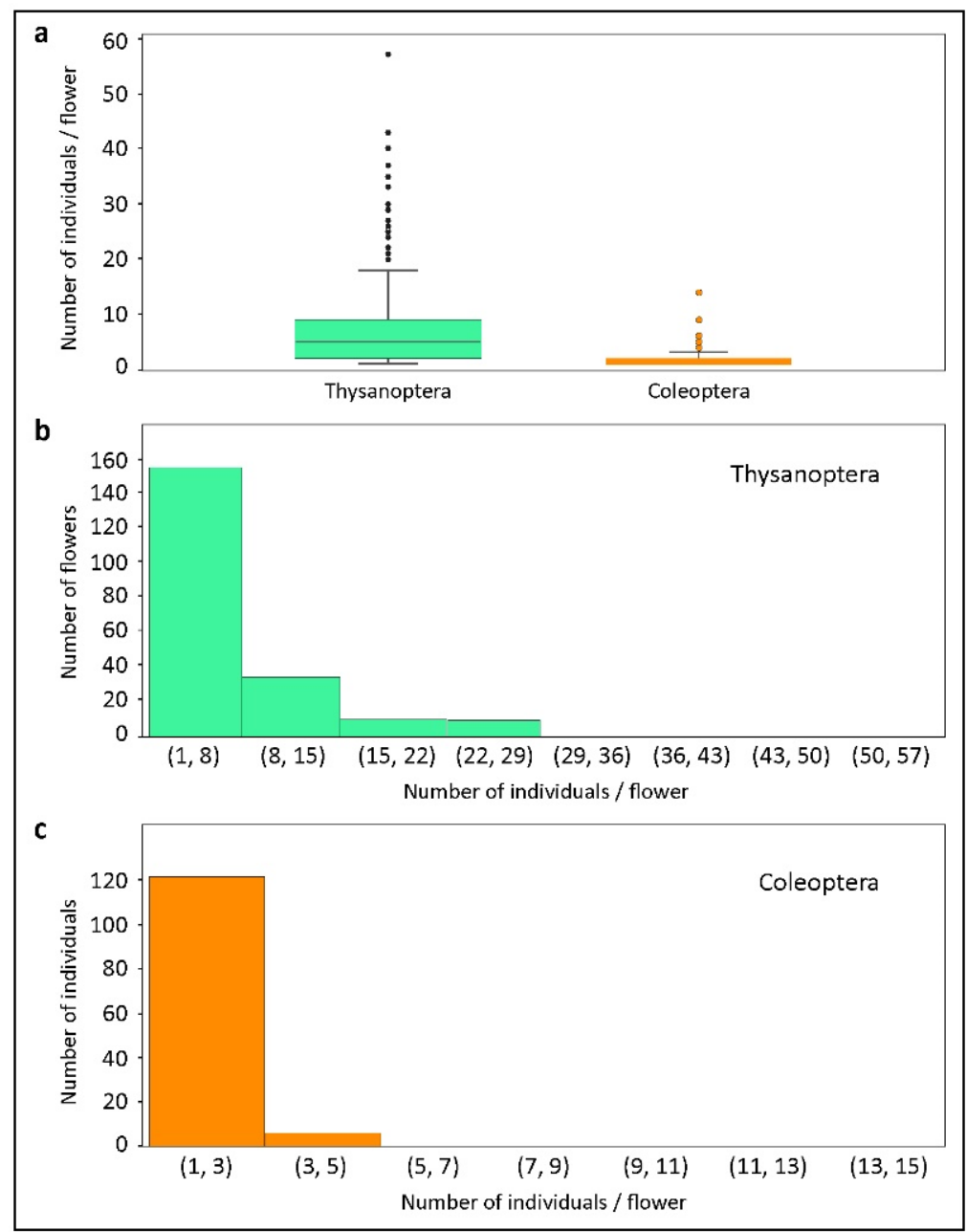

Figure 6. Quantitative data on flower visitors of Xylopia aromatica collected in the Cerrado of Chapada dos Guimarães, MT, Brazil. (a) Abundance distributions of Thysanoptera and Coleoptera per flower. Note that both Thysanoptera (b) and Coleoptera (c) abundances follow a Poisson distribution. There were few events of a high number of individuals/flower $(>1)$ for both orders. 
a

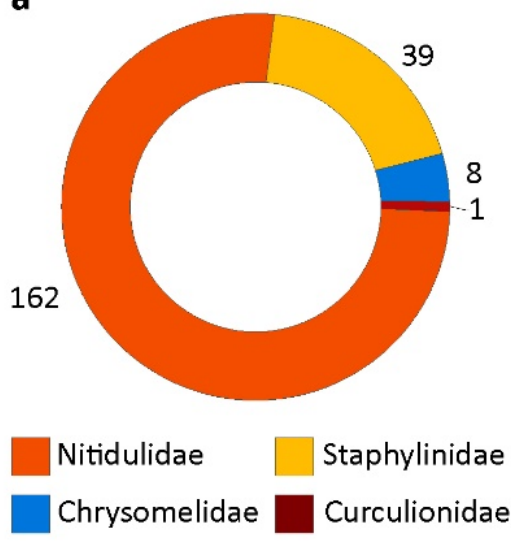

b

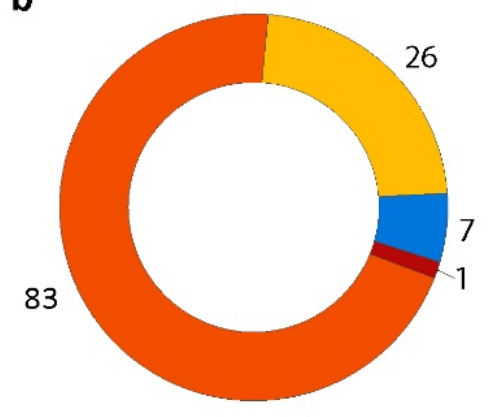

Nitidulidae Staphylinidae

Chrysomelidae Curculionidae

Figure 7. Quantitative data on coleopteran floral visitors of Xylopia aromatica, classified by family, from a Cerrado area in Chapada dos Guimarães, MT, Brazil. (a) Number of adult Coleoptera individuals sorted by family. (b) Number of flowers in which each family of Coleoptera (adults) was present.

Table 2. List of adult coleopteran floral visitors of Xylopia aromatica in 253 flowers sampled in a Cerrado area in Chapada dos Guimarães, MT, Brazil. Ni = total number of individuals of each morphospecies found within flowers. Nf $(\%)=$ percentage of flowers in which each listed morphospecies was found. $\mathrm{Ni} / \mathrm{f}=$ average number of individuals of each morphospecies per flower. P.F.C. $(\%)=$ percentage of individuals of each morphospecies found inside floral chambers. The remaining specimens were found in the alcohol of the samples.

\begin{tabular}{|c|c|c|c|c|}
\hline Family/Subfamily/Species & $\mathbf{N i}$ & Nf $(\%)$ & $\mathrm{Ni} / \mathrm{f}$ & P.F.C. (\%) \\
\hline \multicolumn{5}{|l|}{ Nitidulidae } \\
\hline Conotelus sp. 1 & 159 & 33.2 & 1.91 & 83.64 \\
\hline Carpophilinae sp. 1 & 1 & 0.39 & 1 & 100 \\
\hline Nitidulinae sp. 1 & 1 & 0.39 & 1 & 1 \\
\hline $\begin{array}{l}\text { Meligethinae sp. } 1 \\
\text { Staphylinidae }\end{array}$ & 1 & 0.39 & 1 & 100 \\
\hline Aleocharinae sp. 1 & 27 & 8.3 & 1.28 & 70.37 \\
\hline $\begin{array}{l}\text { Aleocharinae sp. } 2 \\
\text { Chrysomelidae }\end{array}$ & 12 & 4.74 & 1 & 91.66 \\
\hline Lamprosomatinae sp. 1 & 2 & 0.79 & 1 & 100 \\
\hline Lamprosomatinae sp. 2 & 4 & 1.18 & 1.33 & 0 \\
\hline Chrysomelidae sp. 1 & 1 & 0.39 & 1 & 100 \\
\hline $\begin{array}{l}\text { Chrysomelinae sp. } 1 \\
\text { Curculionidae }\end{array}$ & 1 & 0.39 & 1 & 0 \\
\hline Curculionidae sp. 1 & 1 & 0.39 & 1 & 0 \\
\hline Total & 210 & & & \\
\hline
\end{tabular}


a

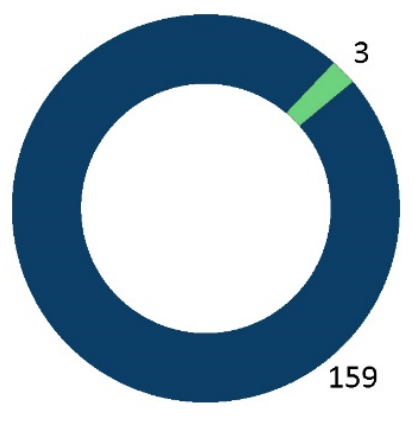

Conotelus sp. 1

Other morphospecies b

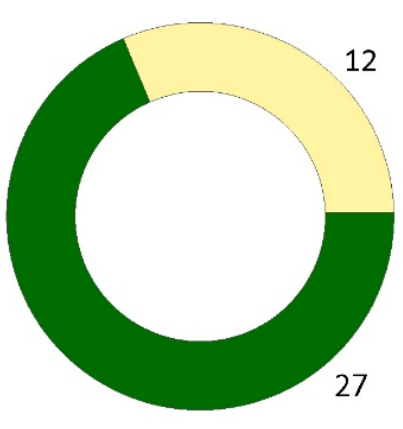

Aleocharinae sp. 1

Aleocharinae sp. 2

Figure 8. Number of adult beetles belonging to morphospecies from the most abundant families collected in flowers of Xylopia aromatica in a Cerrado area in Chapada dos Guimarães, MT, Brazil: Nitidulidae (a) and Staphylinidae (b).

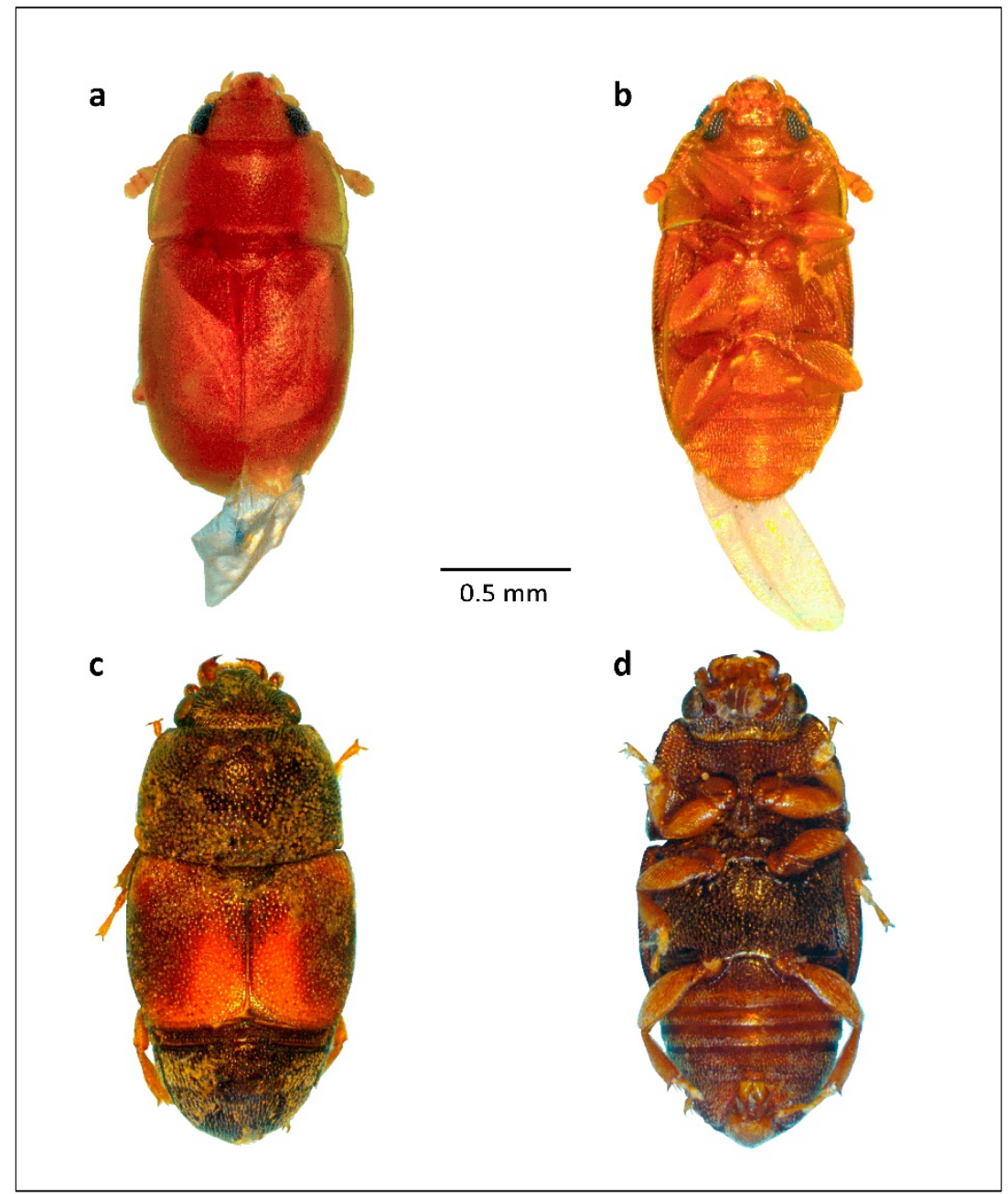

Figure 9. Less frequent floral visitors of Xylopia aromatica from the family Nitidulidae, collected in a Cerrado area in Chapada dos Guimarães, MT, Brazil. Dorsal (a) and ventral (b) habitus of Meligethinae sp. 1 (subfamily Meligethinae). Dorsal (c) and ventral (d) habitus of Carpophilinae sp. 1 (subfamily Carpophilinae). Note the setose body surface of this species, to which floral detritus firmly adheres. 


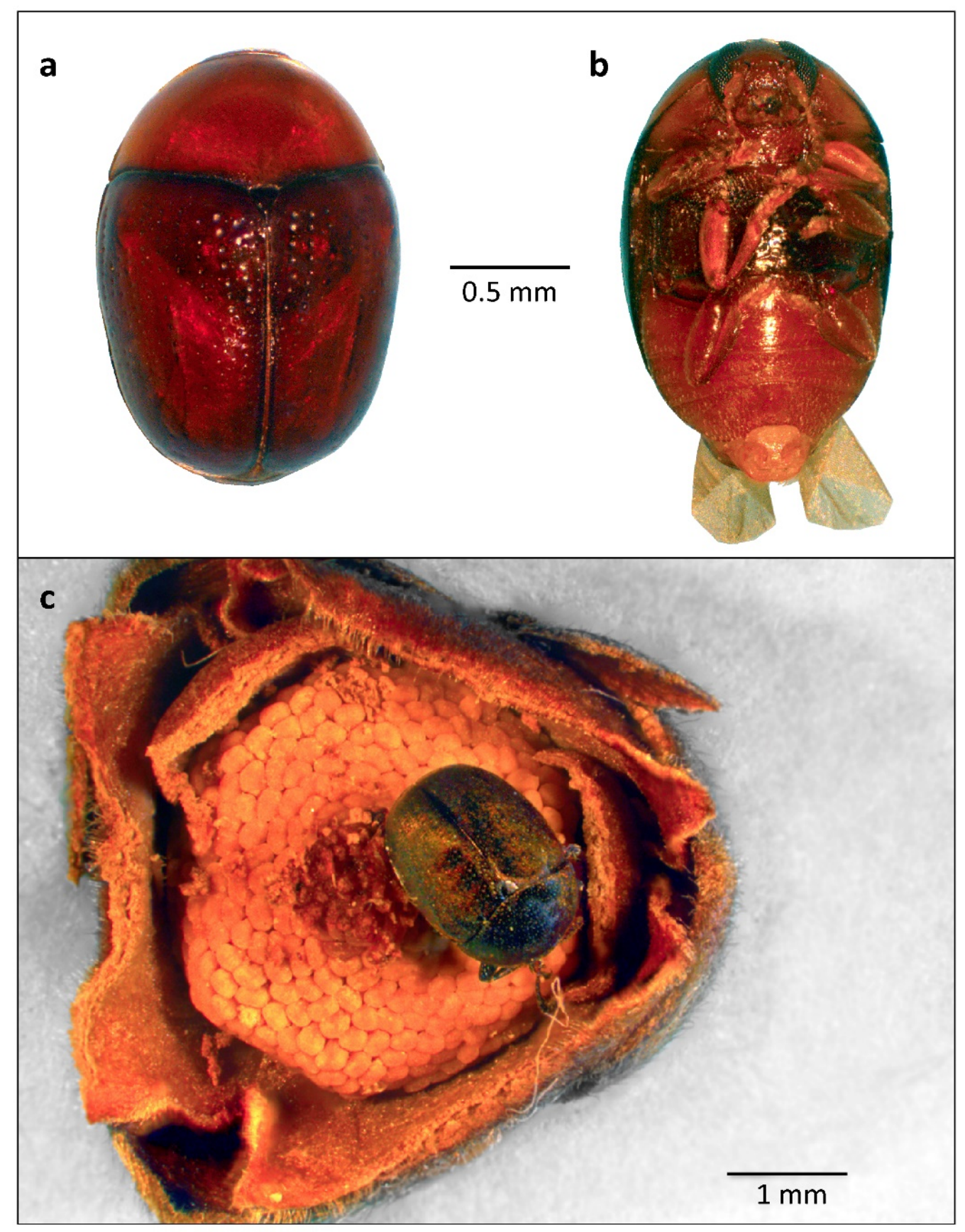

Figure 10. Coleopteran floral visitors of Xylopia aromatica belonging to subfamily Lamprosomatinae (Chrysomelidae), collected in a Cerrado area of Chapada dos Guimarães, MT, Brazil. Dorsal (a) and ventral (b) habitus of Lamprosomatinae sp. 2. (c) Lamprosomatinae sp. 1 inside a floral chamber of $X$. aromatica, adhered to the gynoecium. The corolla has been manually removed for visualization. 


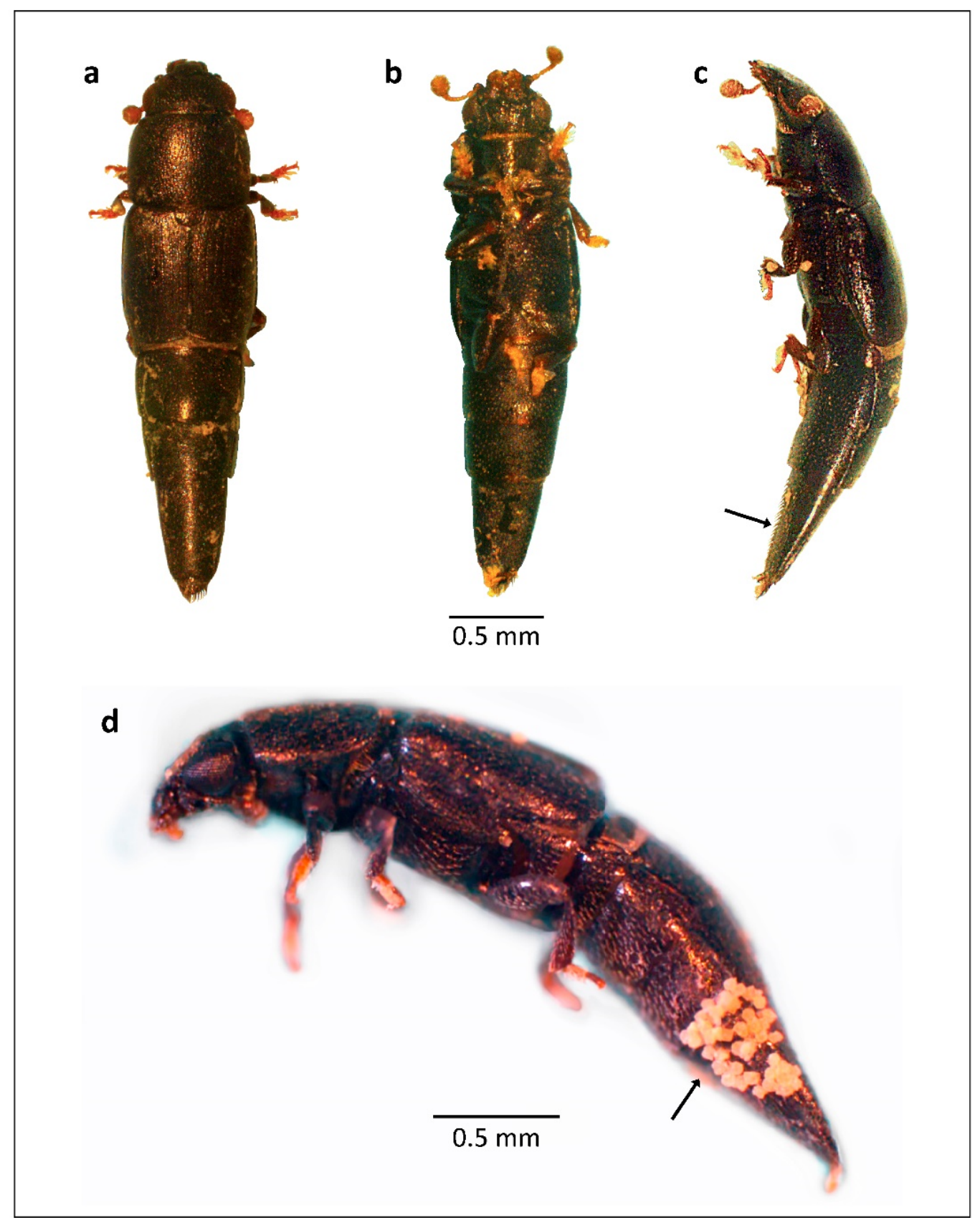

Figure 11. Dorsal (a), ventral (b), and lateral (c) habitus of Conotelus sp. 1, collected in a Cerrado area of Chapada dos Guimarães, MT, Brazil. Note the ventro-abdominal setae of Conotelus sp. 1, where pollen most frequently adheres (arrow). (d) Lateral view of Conotelus sp. 1 with a mass of pollen tetrads of Xylopia aromatica adhered to the ventrolateral setae of the abdomen (arrow). 


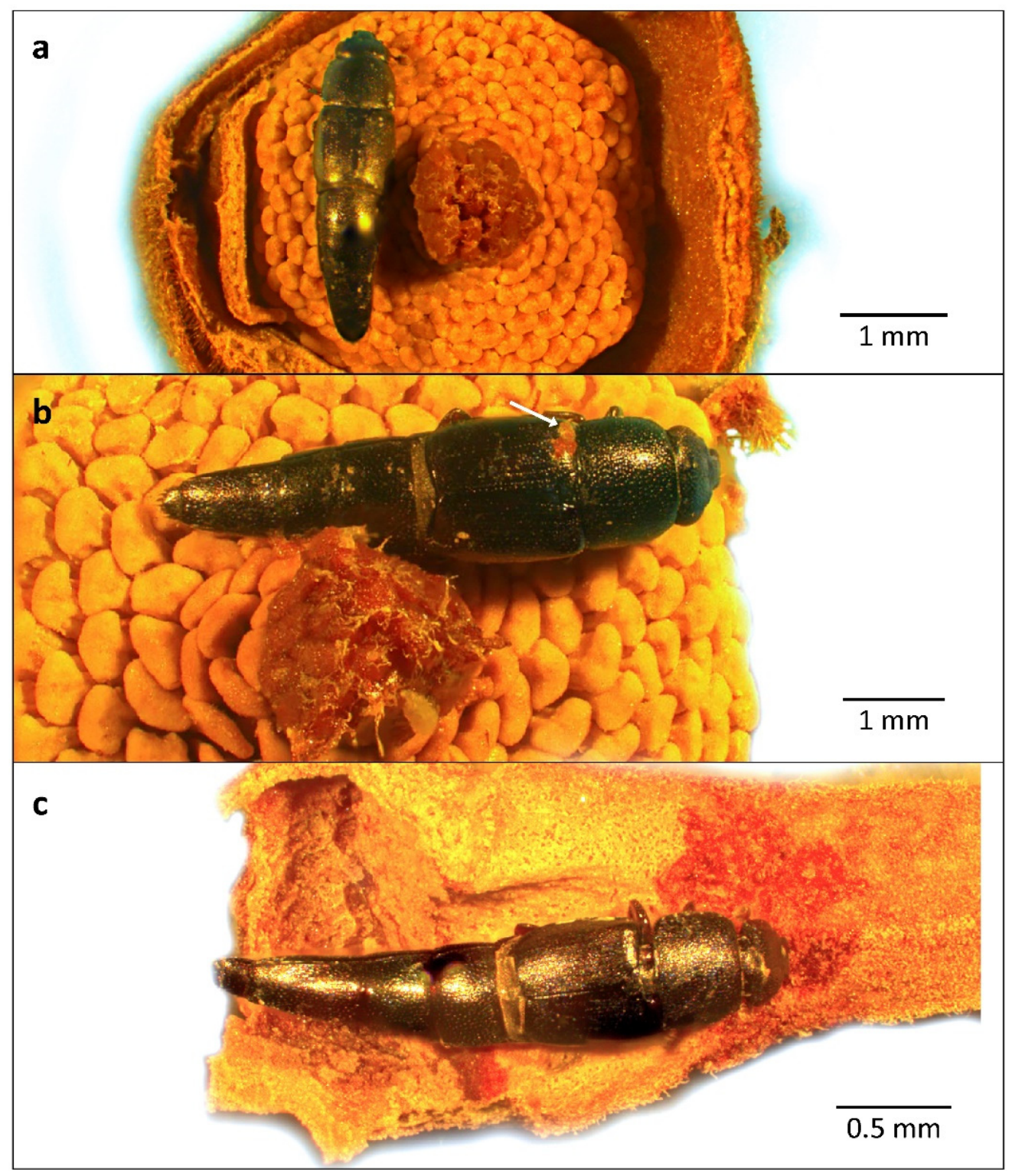

Figure 12. Conotelus sp. 1 individuals found inside floral chambers of Xylopia aromatica, collected in a Cerrado area of Chapada dos Guimarães, MT. Brazil. (a) Conotelus sp. 1 individual over the androecium during the female phase. (b) Conotelus sp. 1 specimen with the abdomen laterally adhered to the gynoecium by stigmatic exudate. Note a pollen tetrad adhered to the base of the left elytron (arrow). (c) Conotelus sp. 1 specimen in the basal concavity of one of the inner petals, apparently feeding on tissue. In $(\mathbf{a}-\mathbf{c})$, the outer petals were manually removed for visualization of the floral chamber and its visitors. 


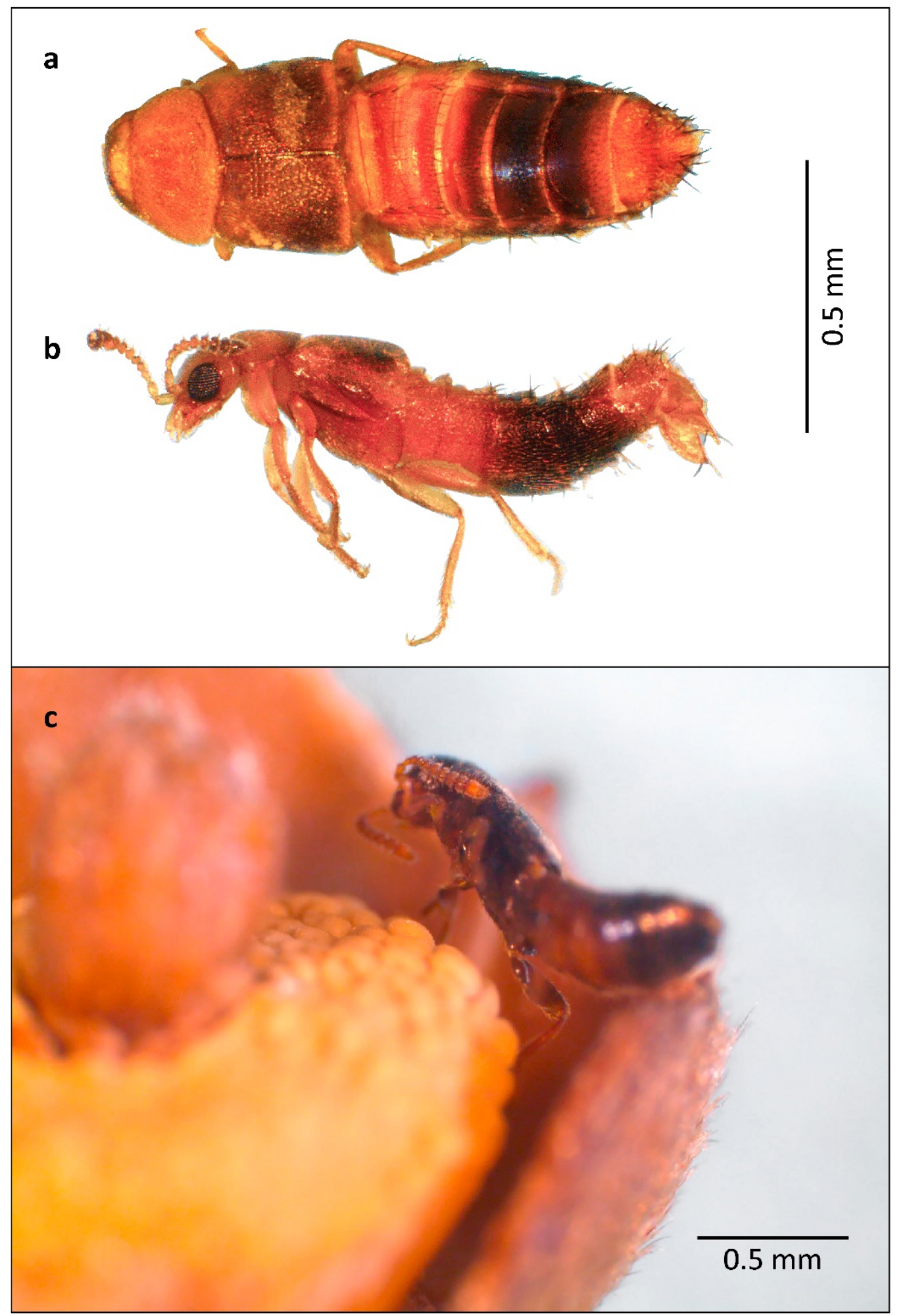

Figure 13. Aleocharinae sp. 1 individuals found inside floral chambers of Xylopia aromatica, collected in a Cerrado area of Chapada dos Guimarães, MT, Brazil. Dorsal (a) and lateral (b) habitus of Aleocharinae sp. 1. (c) Aleocharinae sp. 1 inside a floral chamber over the androecium of X. aromatica. The corolla has been manually removed for visualization. 


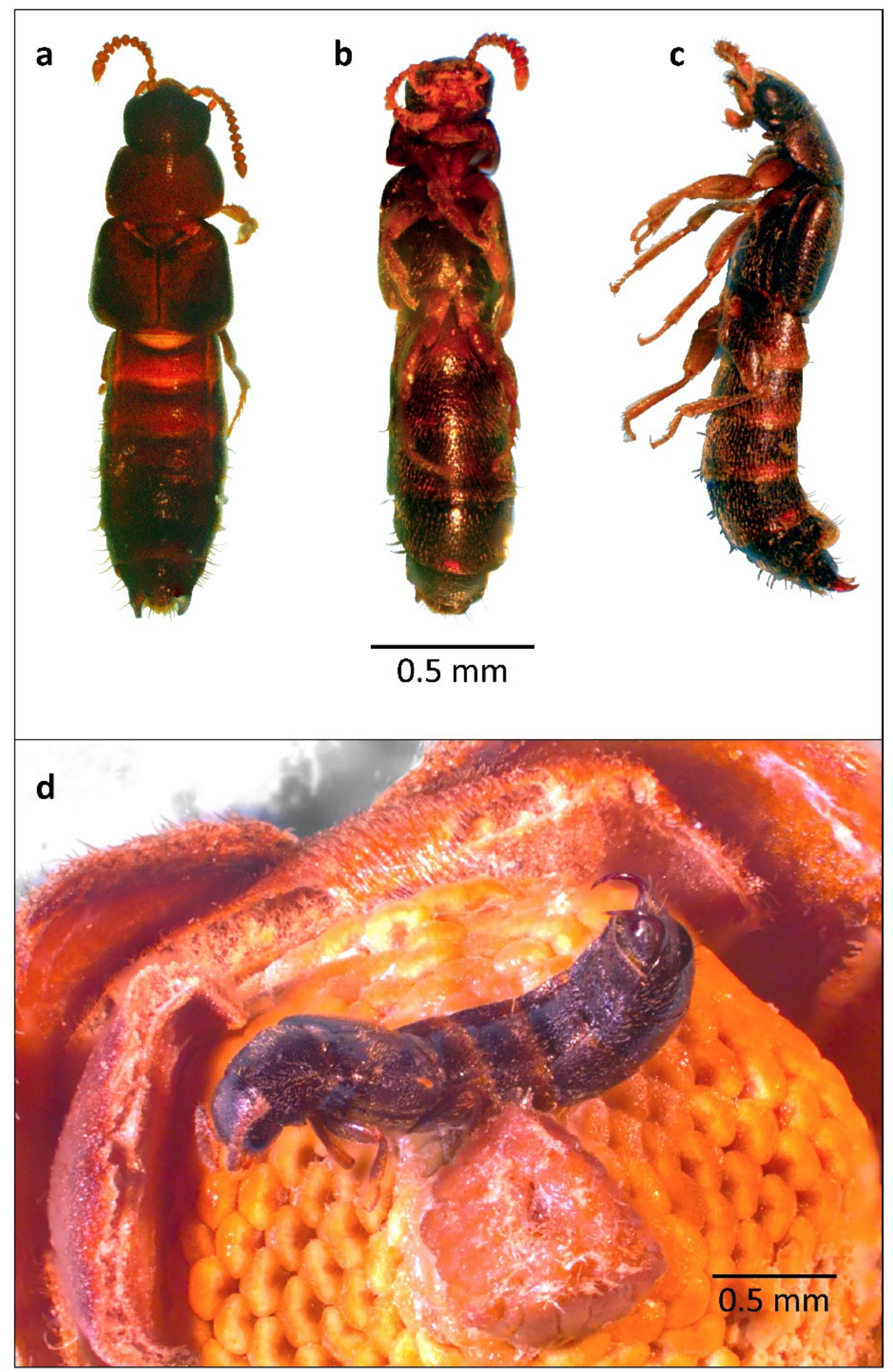

Figure 14. Aleocharinae sp. 2 specimens found inside floral chambers of Xylopia aromatica, collected in a Cerrado of Chapada dos Guimarães, MT, Brazil. Dorsal (a), ventral (b), and lateral (c) habitus of Aleocharinae sp. 2. (d) Aleocharinae sp. 2 with the abdomen laterally adhered to the gynoecium by stigmatic exudate. The corolla was manually removed for visualization. 


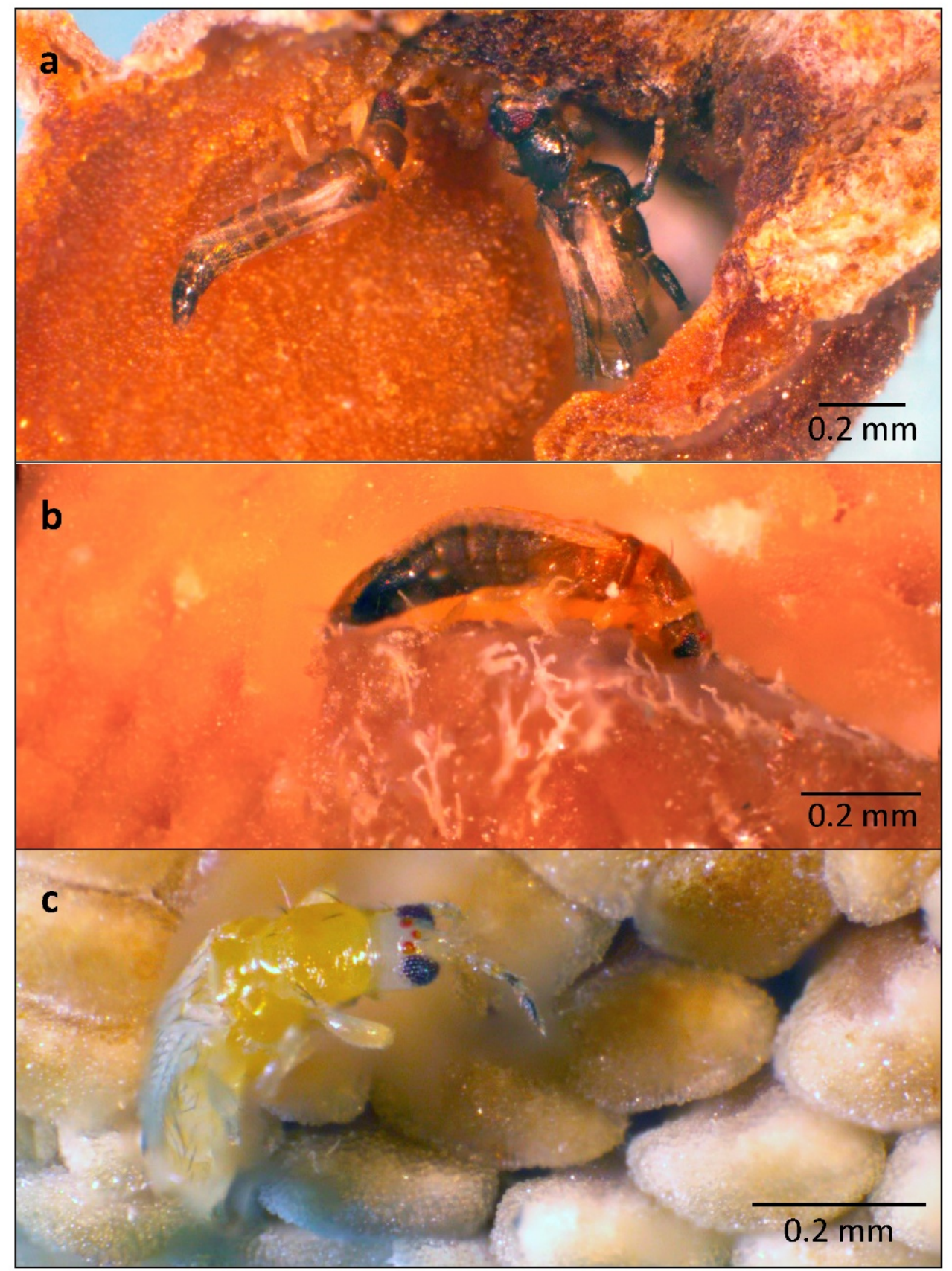

Figure 15. Individuals of Thysanoptera, the most abundant insect order in the flowers of Xylopia aromatica, sampled in a Cerrado area of Chapada dos Guimarães, MT, Brazil. (a) Two individuals of Thysanoptera sucking the concave base of the adaxial surface of an inner petal of an X. aromatica flower. (b) A Thysanoptera feeding on the stigmatic exudate of an X. aromatica flower during the female phase. (c) A teneral Thysanoptera over the stamens of an X. aromatica flower during the female phase. In $(\mathbf{a}-\mathbf{c})$, the corolla has been removed for visualization.

\section{Discussion}

Xylopia aromatica flowers are dichogamous and protogynous, with two distinct anthetic phases: a longer female phase that lasts more than one day and a short male phase that lasts a few hours. Protogynous flowers and inflorescences are associated with cantharophilous blossoms in many plant families, such as Nymphaeaceae, Araceae, Magnoliaceae, and Annonaceae [22,25,42-44].

Beetles and thrips (Thysanoptera) visit $X$. aromatica throughout the first morning of anthesis, when the floral chamber is still open, which persists at most until midday 
(Figure 4). On the other hand, three Xylopia species from Central Amazonia, Xylopia benthamii R.E. Fr., Xylopia crinita R.E. Fr., and Xylopia excellens R.E. Fr., initiate anthesis just before sunset, and their floral chambers remain open until they drop. Nitidulidae and Staphylinidae beetles arrive at their flowers at approximately 18:00. These Amazonian Xylopia species, unlike X. aromatica, present nocturnal anthesis and are thermogenic [45]. It is possible that related beetles are recruited by these plants at different times of the day because their pollinators have bimodal circadian rhythms. The curculionid Endaenidius cf. polyalthiae Kojima et Morimoto, for instance, has a bimodal circadian rhythm, with activity peaks during the early morning hours and around sunset. During its morning activity peak, this beetle is attracted to the flowers of the Chinese Annonaceae Dasymaschalon trichophorum Merr., when in the female phase. During the activity peak of crepuscular hours, E. cf. polyalthiae is once more attracted to the flowers, which imprison them in their chambers throughout the male phase, when pollen is released, to the end of anthesis [20].

Nitidulids of the genus Carpophilus (Carpophilinae) and some staphylinids, which possess a unimodal circadian rhythm and morning activity peak, visit the floral chambers of the Annonaceae species Friesoldielsia borneensis Steenis and Goniothalamus tapisoides MatSalleh during the morning and become trapped in their interior until the following day, after the end of the male phase, when flowers abscise, in a dynamic very similar to that in X. aromatica [20]. However, there are no published data on the circadian rhythm of beetles that visit $X$. aromatica flowers, which may be obtained through field observations and experimental approaches, as shown by Lau et al. [20]. The present study revealed diverging results: whereas Lau et al. [20] affirm that Annonaceae species that present mechanisms of trapping floral visitors tend to have a longer male phase, in order to optimize pollen load, the male phase of $X$. aromatica is relatively brief, not surpassing four hours. This study provides the first record of a brief female phase coupled with a mechanism of circadian trapping of floral visitors in Annonaceae.

The main element attracting beetles to the flowers of X. aromatica appears to be the mildly sweet odor given off by flowers in the female phase, when the floral chamber is open to visitors. Jürgens et al. [46] describe the floral odor of X. aromatica as "sweet", "aromatic" and "pleasant". Curiously, naphthalene, a compound that is commonly used as an insect repellent, is one of the major components of the floral bouquet of X. aromatica as well as $X$. benthamii, both pollinated by Nitidulidae and Staphylinidae [46].

The white color of the inner petals and of the adaxial surface of the outer petals of $X$. aromatica parallels that of other cantharophilous Annonaceae blossoms: the combination of light-colored flowers and sweet, aromatic scents seems to occur in a convergent fashion in different genera of this plant family [46,47]. It is only speculated that, in general, pollinators are attracted to flowers by odor when at a distance and then by color when in proximity to the flowers [48]. The interaction between the reddish color at the base of the inner petals of X. aromatica flowers (Figure 3c) and the perception of it by visitors is also in need of investigation.

The floral scent of basal angiosperms, which may have evolved from compounds associated with plant defense, is a dynamic evolutionary character that requires further exploration from the pollinators' perspective [47]. Male nitidulids of the genus Carpophilus, for example, produce an aggregation pheromone that attracts male as well as female individuals and seems to act in combination with volatile compounds produced by fermenting fruits [49]. Additionally, the bouquet of Xylopia championii Hook. f. et Thomson, native to Sri Lanka, for example, in addition to including volatile substances common to other Annonaceae fruits, contains 11 compounds that have already been identified in insect pheromones. Its flowers emit a sweet scent that attracts weevils of the genus Endaeus (Curculionidae), known for their fruit-eating habits [33]. As shown here, the attraction and aggregation mechanism of the Cillaeinae in relation to the floral chambers of $X$. aromatica may involve more complex elements linked to the mimicry of sexual and/or aggregation pheromones on the plants' part, in synergy with fruity odors. Floral elements responsible for the attraction of Thysanoptera via chemoreception are also of interest. 
Enclosed inside $X$. aromatica floral chambers, the resources offered to their visitors may serve as (1) protection against predators, (2) food in the form of pollen, (3) food in the form of stigmatic exudate, (4) food as vegetal tissue, and (5) aggregation and mating sites. The relevance of each resource mentioned above varies across taxa of floral visitors of $X$. aromatica, which may be determined by observations in situ or in the laboratory or by data from the literature, which is discussed below.

There are numerous records on the role that nitidulids play as pollinators throughout the world, not only for angiosperms but also for gymnosperms: in Japan, the thermogenic cones of Cycas revoluta Thunb. offer, in addition to alimentary resources such as pollen and vegetal tissues, a mating and oviposition site for Carpophilus chalybeus Murray [50]. In addition to Annonaceae, angiosperm groups that may be pollinated by Nitidulidae include Araceae [51], Proteaceae [52], and Arecaceae [48,53]. The nitidulid Mystrops, for instance, feeds on pollen from as well as mates and oviposits on male inflorescences of three palm species of the genus Phytelephas in Ecuador and Colombia [48].

In addition to scant records of their role as pollinators of Annonaceae and Araceae, little is known concerning the biology of the main coleopteran floral visitors of X. aromatica, the nitidulids of the subfamily Cillaeinae $[35,54,55]$. Kirejtshuk, the author of the first description of subfamily Cillaeinae [54], mentions interstices of trees as their usual habitat [55]. Gottsberger [28] and Gottsberger and Silberbauer-Gottsberger [35], not remarking on these beetles' behavior, mention Cillaeus sp. as floral visitors of X. aromatica in Cerrado areas in Mato Grosso, São Paulo, and Minas Gerais, without identifying them at the species level. In our study we found another genus of Cillaeinae, which makes this the first record of a Conotelus species visiting the flowers of $X$. aromatica.

Additionally, in the Cerrado, Paulino-Neto [56] mentions a Cillaeinae species of the genus Colopterus as the principal pollinator of Duguetia furfuracea (A. St.-Hil.) Saff., presenting a behavior suitable for pollination of this species. The flowers of Duguetia furfuracea have an open corolla and, therefore, do not imprison their visitors, instead luring them throughout anthesis by means of an intense mature fruit scent. In the present study, no herbivory marks or foraging behavior was observed through the analysis of floral tissues. The entrapment of these beetles up to the period of anther dehiscence during the male phase seems to indicate that pollen is a major food resource that may be used by Conotelus sp. 1. Moreover, the high sugar content found in the stigmatic exudate of some Annonaceae suggests that it not only favors the germination of pollen grains but also may serve as an alimentary resource for their floral visitors [57]. In fact, in addition to the Thysanoptera that were observed juxtaposed to the gynoecium (Figure 15b), Conotelus sp. 1 (Figure 12b) and Aleocharinae sp. 2 (Figure 14d) were also found adhered to the stigmatic exudate of $X$. aromatica flowers.

The floral chambers of the Annonaceae, providing a location for aggregation without the disturbance of predators or the weather, constitute an adequate place for their visitors to mate $[25,29,58]$. In addition to Thysanoptera, which appeared in dozens (Figure $6 a, b)$ in $X$. aromatica, there was often more than one conspecific beetle per floral chamber (Figure 6c; Table 2). The observation of mating behavior inside floral chambers is, however, very difficult to accomplish because in response to the slightly disturbance and exposition, floral visitors immediately evade. Indirect evidence may be obtained, however, when two sexes of the same species co-occur inside floral chambers and everted genitalia are observed in the material examined in the laboratory.

Pollinivory is known in Staphylinidae, considered by some authors the second most diverse family in the order Coleoptera [59]. In Latin America, Aleocharinae is the most species-rich subfamily of staphylinids [60]. In a study of 27 palm species in nine coastal localities of Colombia, Staphylinidae were collected from 18 of them. Of the 48 listed morphospecies of staphylinids, the largest number, 23 morphospecies, belonged to the subfamily Aleocharinae [61]. In the Cerrado of Chapada dos Guimarães, it was the second most abundant coleopteran group in the flowers of $X$. aromatica, represented by two species (Figures 7 and 8; Table 2). Although no pollen loads were detected in these 
species, their abdominal and antennal setae may serve as adhesion spots for pollen grains (Figures 13 and 14). In general, staphylinids are important pollinators of Annonaceae whose floral chambers are small, as in the genera Xylopia and Anaxagorea, the latter of which is the basal-most genus within the family [25].

The third most frequent group of coleopteran visitors in the flowers of $X$. aromatica were two Chrysomelidae species from the subfamily Lamprosomatinae (Figures 7 and 10; Table 2), a group that is restricted to tropical and subtropical regions [62]. Unidentified specimens of Chrysomelidae were reported in the ample floral chambers of Annona sericea Dunal in Manaus, although a high fruit set was not observed for the flowers included in that study [63]. Andrade et al. [64] observed species of Brachypnoea (Eumolpinae) leaving the floral chambers of Xylopia brasiliensis with their bodies coated in pollen. Gottsberger and Silberbauer-Gottsberger [35] mention Chrysomelidae as pollinators of X. aromatica in Cerrado areas in the states of Amazonas, Mato Grosso, and São Paulo. However, in the present study area, the frequency of pollination of X. aromatica by Lamprosomatinae appears to be, at most, occasional. In addition to the small sample of Lamprosomatinae $(n=6)$, these beetles have glabrous dorsal and ventral surfaces, without structures to which pollen might readily adhere (Figures 7 and 10). Nevertheless, the sticky stigmatic exudate could act as a glue for pollen tetrads, and the influence of geographic and climatic variables may interfere with the abundance of these beetles in the areas where X. aromatica occurs. The present study is the first to record Lamprosomatinae visiting the flower chambers of $X$. aromatica.

If the criteria of pollination efficiency are the presence and abundance of individuals within floral chambers, the main pollinators of X. aromatica are thrips, which has already been stated by Gottsberger [23,28]. Nearly half of thrips species are phytophagous, feeding on the aerial parts of flowers and frequently using their mouth stylets to ingest the cellular contents of pollen grains. The combination of ventral abdominal setae, anal setae, and fringed wings creates an interesting apparatus for pollen capture, especially for the pollen tetrads of X. aromatica, which are smaller than those of other Annonaceae from the Cerrado [65]. However, no pollen loads were found on the setae of Thysanoptera.

Conotelus sp. 1 is the coleopteran species that best matches the criteria for effective pollination used in this research: access to the floral chamber during the female and male phases and the presence of a pollen load. Although the dorsal surface of Conotelus sp. 1 is essentially glabrous, the ventral abdominal surface, which was frequently seen juxtaposed to the gynoecium, possesses setae where pollen grains might readily adhere (Figure 11c,d) in a greater proportion than observed in all other species of floral visitors due to its larger body size.

However, the percentages of visitors found inside the floral chambers with pollen loads are somewhat conservative. Flower visitors, especially beetles, may force their exit from the floral chamber when placed in vials with alcohol. Additionally, pollen grains, unless they are immediately observed after being collected, may detach from the body surface of insects stored in alcohol, which, given the remote location of the study area, becomes a logistic challenge. However, the present study shows, for the first time, body patches on pollinators for the adhesion of pollen grains, especially in Conotelus sp. 1 (Figure 11c,d).

\section{Conclusions}

The economic potential of this Annonaceae species, yet underexplored, is promising. Aromatic oil can be extracted from its flowers, and fruits and seeds serve as a substitute source for spices such as pepper. Seed dispersion is promoted by birds, which avidly feed on the white aril that coats the seeds. In addition, the crown shape and abundant flowering of the species confer ornamental properties [66,67].

In the Cerrado area where this study was conducted, $X$. aromatica appears to present a mixed pollination mode by thrips and beetles involving, in addition to Thysanoptera, Conotelus sp. 1 (Nitidulidae, Cillaeinae) and two species of Aleocharinae (Staphylinidae). 
These pollination vectors, however, are not fixed in space and time. Climatic and geographic variables might affect the taxonomic composition of Annonaceae pollinators together with their reproductive success $[34,35,64]$.

The timeframe of the present study encompassed the first months of the rainy season (16 days from the end of September to December 2019). Different taxa of floral visitors might be sampled in a wider timeframe that would extend over the months of more intense rain, when some individuals of $X$. aromatica are still in bloom. The Poisson distributions indicating the number of beetles per flower (Figure $6 b, c)$, for instance, might be altered because insect abundance in such a markedly seasonal biome, as is the Cerrado, greatly changes over the months of the year [68]. This is the first study on potential pollinators of X. aromatica in the Cerrado of Chapada dos Guimarães. Additional research on the taxonomy and sensorial aspects of potential pollinators could enrich the knowledge about these complex and diversified mutualistic interactions between insects and X. aromatica.

Author Contributions: Conceptualization, F.P.S., K.-L.S. and M.I.M.; methodology, F.P.S., K.-L.S. and M.I.M.; software, F.P.S.; validation: F.P.S., K.-L.S. and M.I.M.; formal analysis, F.P.S., K.-L.S. and M.I.M.; investigation, F.P.S.; resources, M.I.M. and K.-L.S.; data curation, F.P.S. and M.I.M.; writingoriginal draft preparation, F.P.S.; writing—review and editing, K.-L.S. and M.I.M.; visualization, M.I.M., F.P.S. and K.-L.S.; supervision, K.-L.S. and M.I.M.; project administration, M.I.M. and K.-L.S. All authors have read and agreed to the published version of the manuscript.

Funding: F.P.S. was supported by a grant from the Coordenação de Aperfeiçoamento de Pessoal de Nível Superior, Brazil (CAPES), Finance Code 001. K.-L.S. was supported by the Brehm Funds for International Bird Conservation, Bonn, Germany.

Institutional Review Board Statement: Not applicable.

Informed Consent Statement: Not applicable.

Data Availability Statement: Not applicable.

Acknowledgments: We thank Maria Eduarda de Oliveira Basso, Ítalo Rondon, André Luiz Santiago Soares, Filipe Ferreira de Deus, Natanael Rosário Alves da Silva, Fernando Zaiden, Nicholas Grohnert, and Valéria Schmidt for laboratory and field assistance. Daniela Bená (Museum of Zoology, USP, São Paulo, Brazil) and Josef Jelínek (National Museum, Czech Republic) kindly confirmed the generic identification of Nitidulidae morphospecies. Ana Silvia Tissiani helped with the figures. The study was conducted under the Brazilian SISBIO permit number 267603 issued to M.I.M.

Conflicts of Interest: No potential conflict of interest was reported by the authors.

\section{References}

1. Del-Claro, K.; Johnson, M.; Torezan-Silingardi, H.M. Plant-Arthropod Interactions: A Behavioral Approach. Psyche 2012, 2012, 1-2. [CrossRef]

2. Hughes, N.F. Palaeobiology of Angiosperm Origins: Problems of Mesozoic Seed-Plant Evolution; Cambridge University Press: New York, NY, USA, 1976.

3. Crowson, R.A. The Biology of the Coleoptera; Academic Press: London, UK, 1981.

4. Jolivet, P. Food habits and food selection of Chrysomelidae: Bionomic and evolutionary perspectives. In Biology of Chrysome-Lidae; Jolivet, P., Petitpierre, E., Hsiao, T.H., Eds.; Kluwer Academic Publishers: Dordrecht, The Netherlands, $1988 ;$ pp. 1-24.

5. Bartelt, R.J.; Kyhl, J.F.; Ambourn, A.K.; Juzwik, J.; Seybold, S.J. Male-produced aggregation pheromone of Carpophilus sayi, a nitidulid vector of oak wilt disease, and pheromonal comparison with Carpophilus lugubris. Agric. For. Entomol. 2004, 6, 39-46. [CrossRef]

6. Cline, A.R.; Kinnee, S.A. A new species of sap beetle (Coleoptera: Nitidulidae) from Baja California Sur, Mexico, with a review of the genus Lobiopa Erichson. Pan-Pac. Entomol. 2012, 88, 202-211. [CrossRef]

7. Fernandes, D.R.R.; Bená, D.C.; Lara, R.I.R.; Ide, S.; Perioto, N.W. Nitidulidae (Coleoptera) associados a frutos de café (Coffea arabica L.). Coffee Sci. 2012, 7, 135-138.

8. Oliveira, M.A.S.; Genú, P.J.C.; Junqueira, M.T.V.; Pinto, A.C.Q. Pragas da Gravioleira no Cerrado; Embrapa-CPAC: Planaltina, Brazil, 1992; pp. 1-11.

9. Hausmann, C.; Samietz, J.; Dorn, S. Visual Orientation of Overwintered Anthonomus pomorum (Coleoptera: Curculionidae). Environ. Entomol. 2004, 33, 1410-1415. [CrossRef]

10. Vanin, S.A.; Bená, D.D.C.; Albertoni, F.F. Description of immature stages of Phelypera schuppeli (Boheman, 1834) with comments on natural history (Coleoptera: Curculionidae: Hyperinae). Zootaxa 2012, 3423, 45-60. [CrossRef] 
11. Oliveira, L.J.; Santos, B.; Parra, J.R.P.; Amaral, M.L.B.D.; Magri, D.C. Ciclo Biológico de Phyllophaga cuyabana (Moser) (Scarabaeidae: Melolonthinae). An. Soc. Entomol. Bras. 1996, 25, 431-437. [CrossRef]

12. Rodrigues, S.R.; Barbosa, C.A.F.; Fuhrmann, J.; Amaro, R.A. Mating behavior and description of immature stages of Cyclocephala melanocephala (Fabricius, 1775) (Coleoptera: Scarabaeidae: Dynastinae), identification key and remarks on known immatures of Cyclocephalini species. Rev. Bras. Entomol. 2018, 62, 205-219. [CrossRef]

13. Barfod, A.S.; Hagen, M.; Borchsenius, F. Twenty-five years of progress in understanding pollination mechanisms in palms (Arecaceae). Ann. Bot. 2011, 108, 1503-1516. [CrossRef]

14. Elias, M.A.S.; Franceschinelli, E.V.; Juen, L.; Borges, F.J.A.; Ferreira, G.M.; Carvalho, F.M.V. Reproductive success of Cardiopetalum calophyllum (Annonaceae) treelets in fragments of Brazilian savanna. J. Trop. Ecol. 2012, 28, 317-320. [CrossRef]

15. Teichert, H.; Dötterl, S.; Frame, D.; Kirejtshuk, A.; Gottsberger, G. A novel pollination mode, saprocantharophily, in Duguetia cadaverica (Annonaceae): A stinkhorn (Phallales) flower mimic. Flora 2012, 207, 522-529. [CrossRef]

16. Tsukada, M.; Inui, M.; Suzaki, N. Do beetles prefer the odor of female-stage to male-stage flowers in Atemoya, a cantharo-phylous protogynous fruit tree (Annonaceae)? J. Entomol. Res. Soc. 2017, 19, 43-52.

17. Saravy, F.P.; Marques, M.I.; Schuchmann, K.-L. Coleopteran Pollinators of Annonaceae in the Brazilian Cerrado-A Review. Diversity 2021, 13, 438. [CrossRef]

18. Silberbauer-Gottsberger, I. Pollination and evolution in palms. Phyton 1990, 30, 213-233.

19. Eriksson, R. The remarkable weevil pollination of the neotropical Carludovicoideae (Cyclanthaceae). Plant Syst. Evol. 1994, 189, 75-81. [CrossRef]

20. Lau, J.Y.Y.; Guo, X.; Pang, C.-C.; Tang, C.C.; Thomas, D.C.; Saunders, R.M.K. Time-Dependent Trapping of Pollinators Driven by the Alignment of Floral Phenology with Insect Circadian Rhythms. Front. Plant Sci. 2017, 8, 1119. [CrossRef] [PubMed]

21. Medeiros, B.A.S.D.; Núñez-Avellaneda, A.L.; Hernandez, A.M.; Farrell, B.D. Flower visitors of the licuri palm (Syagrus coronata): Brood pollinators coexist with a diverse community of antagonists and mutualists. Biol. J. Linn. Soc. 2019, 126, 666-687. [CrossRef]

22. Gibernau, M.; Barabé, D.; Cerdan, P.; Dejean, A. Beetle pollination of Philodendron solimoesense (Araceae) in French Guiana. Int. J. Plant Sci. 1999, 160, 1135-1143. [CrossRef]

23. Gottsberger, G. Pollination and evolution in neotropical Annonaceae. Plant Species Biol. 1999, 14, 143-152. [CrossRef]

24. De Almeida-Júnior, E.B.; Collevatti, R.G.; Telles, M.P.D.C.; Chaves, L.J.; Neres, D.F.; Soares, T. Short-distance pollen dispersal in a protogynous Annonaceae tree species from the Brazilian Cerrado. Plant Syst. Evol. 2018, 304, 1091-1099. [CrossRef]

25. Gottsberger, G. How diverse are Annonaceae with regard to pollination? Bot. J. Linn. Soc. 2012, 169, 245-261. [CrossRef]

26. Souza, V.C.; Lorenzi, H. Botânica Sistemática: Guia Ilustrado para Identificação das Famílias Nativas e Exóticas no Brasil, Baseado em APG III; Instituto Plantarum: Nova Odessa, Brazil, 2012.

27. Couvreur, T.L.P.; Helmstetter, A.J.; Koenen, E.J.M.; Bethune, K.; Brandão, R.D.; Little, S.A.; Sauquet, H.; Erkens, R.H.J. Phylogenomics of the major tropical plant family Annonaceae using targeted enrichment of nuclear genes. Front. Plant Sci. 2019, 9, 1491. [CrossRef] [PubMed]

28. Gottsberger, G. As anonáceas do cerrado e a sua polinização. Braz. J. Biol. 1994, 54, 391-402.

29. Costa, M.S.; Silva, R.J.; Paulino-Neto, H.F.; Pereira, M.J.B. Beetle pollination and flowering rhythm of Annona coriacea Mart. (Annonaceae) in Brazilian cerrado: Behavioral features of its principal pollinators. PLoS ONE 2017, 12, e0171092. [CrossRef] [PubMed]

30. Parizotto, D.R.; Grossi, P.C. Revisiting pollinating Cyclocephala scarab beetles (Coleoptera: Melolonthidae: Dynastinae) as-sociated with the soursop (Annona muricata, Annonaceae). Neotrop. Entomol. 2018, 48, 415-421. [CrossRef]

31. Forzza, R.C.; Baumgratz, J.F.A.; Costa, A.; Hopkins, M.; Leitman, P.M.; Lohmann, L.G.; Martinelli, G.; Morim, M.P.; Coelho, M.A.N.; Peixoto, A.L.; et al. As Angiospermas do Brasil. In Catálogo de Plantas e Fungos do Brasil; Forzza, R.C., Leitman, P.M., Costa, A., de Carvalho, A.A., Jr., Peixoto, A.L., Walter, B.M.T., Bicudo, C., Zappi, D., da Costa, D.P., Lleras, E., et al., Eds.; Instituto de Pesquisas do Jardim Botânico do Rio de Janeiro: Rio de Janeiro, Brazil, 2010; Volume 1, pp. 78-89.

32. Mendonça, R.C.; Felfili, J.F.; Walter, B.M.T.; Silva-Júnior, M.C.; Rezende, A.V.; Filgueiras, T.S.; Nogueira, P.E.; Fagg, C.F. Flora vascular do bioma Cerrado-Checklist com 12.356 espécies. In Cerrado-Ecologia e Flora; Sano, S.M., de Almeida, S.P., Ribeiro, J.F., Eds.; Embrapa Informação Tecnológica: Brasília, Brazil, 2008; Volume 2, pp. 421-1181.

33. Ratnayake, R.M.C.S.; Gunatilleke, I.A.U.N.; Wijesundara, D.S.A.; Saunders, R.M.K. Pollination Ecology and Breeding System of Xylopia championii (Annonaceae): Curculionid Beetle Pollination, Promoted by Floral Scents and Elevated Floral Temperatures. Int. J. Plant Sci. 2007, 168, 1255-1268. [CrossRef]

34. Aragão, D.D.S.; Costa, C.B.N.; Nascimento, V.T.D. Biologia floral, fenologia reprodutiva e polinização de Xylopia aromatica (Lam.) Mart. (Annonaceae) em uma área de Cerrado no oeste da Bahia. Paubrasilia 2019, 2, 17-26. [CrossRef]

35. Gottsberger, G.; Silberbauer-Gottsberger, I. In the evening when the beetles come: Pollination in Annonaceae and Philodendron. In Life in the Cerrado: A South American Tropical Seasonal Vegetation; Reta Verlag: Ulm, Germany, 2006; Volume 2, Chapter 15, pp. 138-158.

36. GBIF-Global Biodiversity Information Facility. Xylopia aromatica (Lam.) Mart. Available online: https://www.gbif.org (accessed on 26 September 2021).

37. Ribeiro, J.F.; Walter, B.M.T. As principais fitofisionomias do bioma Cerrado. In Cerrado: Ecologia e Flora; Sano, S.M., de Almeida, S.P., Ribeiro, J.F., Eds.; Embrapa Informação Tecnológica: Brasília, Brazil, 2008; Volume 1, pp. 151-212.

38. Vieira-Júnior, H.T.; Moraes, J.M.; de Paula, T.L.F. Chapada dos Guimarães (MT). In Geoparques do Brasil: Propostas; Schobben-haus, C., da Silva, C.R., Eds.; CPRM: Rio de Janeiro, Brazil, 2012; Volume 1, pp. 283-316. 
39. Brusca, R.C.; Moore, W.; Schuster, S.M. Invertebrates, 3rd ed.; Sinauer Associates: Sunderland, MA, USA, 2016.

40. Bouchard, P.; Bousquet, Y.; Davies, A.; Alonso-Zarazaga, M.; Lawrence, J.; Lyal, C.; Newton, A.; Reid, C.; Schmitt, M.; Slipinski, A.; et al. Family-Group Names In Coleoptera (Insecta). ZooKeys 2011, 88, 1. [CrossRef]

41. Habeck, D.H. Nitidulidae Latreille. In American Beetles-Polyphaga: Scarabaeoidea through Curculionoidea; Arnett, R.H., Thomas, M.C., Skelley, P.E., Frank, J.H., Eds.; CRC Press: Boca Raton, CA, USA, 2002; Volume 2, pp. 311-315.

42. Dieringer, G.; Cabrera, R.L.; Lara, M.; Loya, L.; Reyes-Castillo, P. Beetle Pollination and Floral Thermogenicity in Magnolia tamaulipana (Magnoliaceae). Int. J. Plant Sci. 1999, 160, 64-71. [CrossRef]

43. Ervik, F.; Knudsen, J.T. Water lilies and scarabs: Faithful partners for 100 million years? Biol. J. Linn. Soc. 2003, 80, 539-543. [CrossRef]

44. Paulino-Neto, H.F. Polinização por besouros. In Biologia da Polinização; Rech, A.R., Agostini, K., Oliveira, P.E., Machado, I.C., Eds.; Projeto Cultural: Rio de Janeiro, Brazil, 2014; pp. 259-275.

45. Küchmeister, H.; Webber, A.C.; Silberbauer-Gottsberger, I.; Gottsberger, G. A polinização e sua relação com a termogênese em espécies de Arecaceae e Annonaceae da Amazônia Central. Acta Amazon. 1998, 28, 217-245. [CrossRef]

46. Jürgens, A.; Webber, A.C.; Gottsberger, G. Floral scent compounds of Amazonian Annonaceae species pollinated by small beetles and thrips. Phytochemistry 2000, 55, 551-558. [CrossRef]

47. Goodrich, K.R. Floral scent in Annonaceae. Bot. J. Linn. Soc. 2012, 169, 262-279. [CrossRef]

48. Ervik, F.; Tollsten, L.; Knudsen, J.T. Floral scent chemistry and pollination ecology in phytelephantoid palms (Arecaceae). Plant Syst. Evol. 1999, 217, 279-297. [CrossRef]

49. Dowd, P.F.; Bartelt, R.J. Aggregation pheromone glands of Carpophilus freemani (Coleoptera: Nitidulidae) and gland distri-bution among other sap beetles. Ann. Entomol. Soc. Am. 1993, 86, 464-469. [CrossRef]

50. Kono, M.; Tobe, H. Is Cycas revoluta (Cycadaceae) wind- or insect-pollinated? Am. J. Bot. 2007, 94, 847-855. [CrossRef]

51. Milet-Pinheiro, P.; Gonçalves, E.G.; Navarro, D.M.D.A.F.; Nuñez-Avellaneda, L.A.; Maia, A. Floral scent chemistry and pollination in the Neotropical aroid genus Xanthosoma (Araceae). Flora 2017, 231, 1-10. [CrossRef]

52. Hemborg, A.M.; Bond, W.J. Different rewards in female and male flowers can explain the evolution of sexual dimorphism in plants. Biol. J. Linn. Soc. 2005, 85, 97-109. [CrossRef]

53. Meléndez, M.R.; Ponce, W.P. Pollination in the oil palms Elaeis guineensis, E. oleifera and their hybrids (OxG), in tropical America. Pesqui. Agropecuária Trop. 2016, 46, 102-110. [CrossRef]

54. Kirejtshuk, A.G. On polyphyly of the Carpophilinae with description of a new subfamily, Cillaeinae (Coleoptera: Nitidulidae). Coleopt. Bull. 1986, 40, 217-221.

55. Kirejtshuk, A.G.; Kovalev, A.V. A new genus of the subfamily Cillaeinae (Coleoptera, Nitidulidae) from the Philippines and New Guinea with notes on the taxonomy and phylogeny of the subfamily. Zootaxa 2016, 4205, 226. [CrossRef]

56. Paulino-Neto, H.F. História Natural e Interação Flores-Besouros em Espécies de Cerrado. Ph.D. Thesis, Universidade de São Paulo, São Paulo, Brazil, 2009.

57. Lau, J.Y.Y.; Pang, C.C.; Ramsden, L.; Saunders, R.M.K. Stigmatic exudate in the Annonaceae: Pollinator reward, pollen germination medium or extragynoecial compitum? J. Integr. Plant Biol. 2017, 59, 881-894. [CrossRef]

58. Gottsberger, G. Comments on flower evolution and beetle pollination in the genera Annona and Rollinia (Annonaceae). Plant Syst. Evol. 1989, 167, 189-194. [CrossRef]

59. Casari, S.A.; Ide, S. Coleoptera Linnaeus. In Insetos do Brasil: Diversidade e Taxonomia; Albertino, J.A., Melo, G.A.R., de Carvalho, C.J.B., Casari, S.A., Constantino, R., Eds.; Holos Editora: Ribeirão Preto, Brazil, 2012; pp. 454-535.

60. Asenjo, A.; Klimaszewski, J.; Chandler, D.S.; Fierros-López, H.E.; Vieira, J.S. Staphylinidae (Insecta: Coleoptera) in Latin America: Synopsis, annotated catalog, diversity and distribution. Zootaxa 2019, 4621, 1-406. [CrossRef]

61. Niño-Pérez, A.E.; Núñez-Avellaneda, L.A. Diversidad y especificidad de estafilinidos (Coleoptera: Staphylinidae) asociados con inflorescencias de palmas silvestres en el Pacífico colombiano. Rev. Biodivers. Neotrop. 2018, 8, 94-107.

62. Bukejs, A.; Nadein, K. First fossil Lamprosomatinae leaf beetles (Coleoptera: Chrysomelidae) with descriptions of new genera and species from Baltic amber. Zootaxa 2015, 3931, 127-139. [CrossRef]

63. Webber, A.C. Alguns aspectos da biologia floral de Annona sericea Dun. (Annonaceae). Acta Amaz. 1981, 11, 61-65. [CrossRef]

64. Andrade, B.M.; Oliveira-Filho, A.T.; Soares, A.R. Pollination and breeding system of Xylopia brasiliensis Sprengel (Annonaceae) in south-eastern Brazil. J. Trop. Ecol. 1996, 12, 313-320. [CrossRef]

65. Monteiro, R.C.; Mound, L.A. Thysanoptera Haliday. In Insetos do Brasil: Diversidade e Taxonomia; Albertino, J.A., Melo, G.A.R., de Carvalho, C.J.B., Casari, S.A., Constantino, R., Eds.; Holos Editora: Ribeirão Preto, Brazil, 2012; pp. $408-422$.

66. Lorenzi, H. Árvores Brasileiras: Manual de Identificação e Cultivo de Plantas Arbóreas Nativas do Brasil; Plantarum: Nova Odessa, Brazil, 1992.

67. Silva-Júnior, M.C.; Dos Santos, G.C.; Nogueira, P.E.; Munhoz, C.B.R.; Ramos, A.E. 100 Árvores do Cerrado: Guia de Campo; Rede de Sementes do Cerrado: Brasília, Brazil, 2005.

68. Silva, N.A.P.; Frizzas, M.A.; Oliveira, C.M. Seasonality in insect abundance in the "Cerrado" of Goiás State, Brazil. Rev. Bras. Entomol. 2011, 55, 79-87. [CrossRef] 